\title{
The systematics of Seminavis (Bacillariophyta): the lost identities of Amphora angusta, $A$. ventricosa and $A$. macilenta
}

\author{
D. B. DANIELIDIS ${ }^{1}$ AND D. G. MANN ${ }^{2}$ \\ ${ }^{1}$ University of Athens, Faculty of Biology, Department of Ecology and Systematics, Panepistimiopolis, Athens 15784, Greece \\ ${ }^{2}$ Royal Botanic Garden, Edinburgh EH3 5LR, Scotland, UK
}

(Received 5 February 2001; accepted 12 March 2002)

\begin{abstract}
Amphora angusta Gregory, Amphora ventricosa Gregory and Amphora macilenta Gregory have been misunderstood for the last 140 years. Gregory described these species from sublittoral sediments off the west coast of Scotland. Although the illustrations were excellent for their time (1857), it is impossible to be confident of identification using Gregory's paper, and subsequent authors have created such confusion that records of these taxa must be regarded as untrustworthy unless backed by photographic evidence. In this paper, the first to describe in detail the recently established genus Seminavis, we show that $A$. angusta is in fact a species of Amphora Ehrenberg, whereas A. ventricosa sensu Gregory represents two independent species of the genus Seminavis D. G. Mann, namely Seminavis ventricosa (Gregory) Garcia-Baptista (non S. ventricosa sensu Garcia-Baptista 1993) and Seminavis arranensis Danielidis \& D. G. Mann, sp. nov. The form usually known as $A$. ventricosa is neither of these and requires a new name, Seminavis robusta Danielidis \& D. G. Mann, sp. nov. The long forgotten and misclassified species $A$. macilenta Gregory is shown to be yet another Seminavis species, requiring a new combination as S. macilenta (Gregory) Danielidis \& D. G. Mann, comb. nov.; contrary to previous claims, it is separate from A. ergadensis Gregory, which is a true Amphora. Valve and girdle ultrastructure, plastid arrangement and auxosporulation are described for Seminavis and resemble those in the Naviculaceae sensu stricto.
\end{abstract}

Key words: Bacillariophyta, diatoms, marine benthic diatoms, morphology, new taxa, Seminavis, taxonomy

\section{Introduction}

Mann \& Droop (1996) have raised the estimate of diatom species worldwide to 200000 , based on a narrower species concept than that currently applied (Mann, 1999). A considerable contribution to this increased total comes from resolving misinterpreted, heterogeneous species published during the nineteenth or early twentieth centuries. Often, a number of different forms, from various habitats and locations, have been wrongly grouped into one or a few species. Examples are the Diploneis bomboides (A. Schmidt) Cleve and D. smithii-fusca complexes (Droop, 1994, 1995a, 1996a, b; Droop et al., 2000), and Sellaphora pupula (Kützing) Mereschkowsky (Mann, 1984, 1989 b, 1999; Mann \& Droop, 1996). These misinterpretations are the result of microscope inadequacies, poor illustrations and lack of critical comparison with type material, as well as inattention to protoplast features and autecology. Furthermore, the application of a broad species concept and the universal use of 'europocentric' floras, on the assumption that most diatom species are cosmopolitan (Hustedt, 1931-59; Kram-

Correspondence to: D. B. Danielidis. e-mail: ddaniel@cc.uoa.gr mer \& Lange-Bertalot, 1986-91), have added to the confusion.

In the present case, a poor original illustration of Amphora angusta Gregory (1857) and a failure to examine authentic specimens of this species have created taxonomic confusion over the identities of several species lasting for 140 years. The aims of this study are to provide the first detailed account of the recently established genus Seminavis D. G. Mann in Round et al. (1990); to clarify the identity of Amphora angusta Gregory, which is a true Amphora; and to describe morphotypes of $A$. ventricosa Gregory as discrete species under the genus Seminavis. Additionally, the forgotten and misclassified species A. macilenta, which Gregory (1857) described from the same locality as $A$. angusta and $A$. ventricosa, is shown to be yet another Seminavis species.

\section{Materials and methods}

Gregory's type material of Amphora angusta and A. ventricosa in the Greville collection at the Natural History Museum, London (BM) was studied, as well as subtidal (c. $10 \mathrm{~m}$ deep) samples from Loch Goil, Argyll, Scotland (National Grid Reference NS 1999), collected in 19881990 by Dr R. A. Park (Royal Botanic Garden Edinburgh, E). Crude cultures from Loch Goil were grown for 
1-2 weeks in seawater enriched with N, P and Si stocks of WC medium (Guillard \& Lorenzen, 1972). Recent samples were prepared by an adaptation of the Eaton \& Moss (1966) lens tissue method (Mann, 1994). Additional material for some related species was examined from the Messolonghi lagoon complex (western Greece); this was collected from marine and brackish habitats in the littoral zone during 1984-8 (Athens Diatom Herbarium, ADH). Diatom slides were prepared by mounting acid-cleaned material in Naphrax. A Reichert Polyvar 2 photomicroscope with bright field (BF), differential interference contrast (DIC) and phase contrast (PhC) optics was used for light microscopy (LM). Photographs were taken on Kodak Technical Pan film. Scanning electron microscopy (SEM) was performed with a Zeiss DSM 962 operating at $15 \mathrm{kV}$. Stria densities were measured under the microscope or from published drawings and photographs using a Universal Striatometer (Droop, 1995b). The England Finder readings given in the text follow Droop's (1996a) recommendations.

On the labels of the slides that Greville used for drawing Gregory's taxa, he sometimes recorded the coordinates of the specific specimen he drew, using a Maltwood Finder (now unavailable) together with a dot, which was marked close to the scripted finder reference. We found that the positions of these dots in relation to the finder reference are significant: they mark the position of the relevant individual when the slide has been moved to the finder reference. Consequently, we were able to accurately locate specific individuals of all the species that were mentioned on the slide labels. On other occasions, the Maltwood Finder references corresponded to spots marked directly on the coverslip, possibly identifying the positions of individual diatoms. In slides Gregory gave to Professor G. Walker Arnott (held at the Royal Botanic Garden, Edinburgh), spots are again present, so it is virtually certain that Greville drew particular specimens, identified by dots marked by Gregory, on Gregory's instructions.

Since no Maltwood Finder is exactly the same as another, an empirical correction was made of the original references to references of the Maltwood Finder available at Edinburgh (nominator minus 2, denominator plus 10). This correction was consistent and accurate for all the slides and all the individuals mentioned on the labels, even when applied to other Greville slides that were on loan to us at the time. Droop (1996a) used the same Maltwood Finder for locating Diploneis species on other Gregory slides and found that his deviation was also consistent but not exactly the same as ours. This was the combined result of not applying the 'spot' concept in locating the individuals and of the different physical dimensions (especially the width) of the slides involved.

\section{Observations}

\section{Taxonomic history}

Gregory established Amphora angusta and A. ventricosa in 1857 from material collected by himself and others from the Firth of Clyde (off the Isle of Arran and in Loch Fine, western Scotland). According to the original description, A. angusta is a small, slender, barrel-shaped Amphora with arched raphe branches, simple girdle and fine striae (Gregory, 1857 , p. 510, fig. 66). These characters can be recognized, although with some difficulty, in the drawing by Greville that accompanies the publication. Amphora ventricosa is a larger species, linear-lanceolate in girdle view, with a straight or slightly bowed raphe, but again with a simple girdle. In the following years confusion developed over the identity and taxonomic characters of these species, caused probably by Cleve's (1895) account. Cleve admitted that he had not seen specimens of $A$. angusta but, based on stria density, he decided that forms similar to one illustration in A. Schmidt's Atlas (1875, pl. 25, fig. 15; which bears a gross resemblance to $A$. ventricosa) are representative of the species. At the same time he placed several other species of Amphora subgenus Cymbamphora Cleve, including $A$. ventricosa, as varieties of $A$. angusta, but treated some forms clearly resembling the original illustration and description of $A$. angusta (viz. A. angusta f. minuta in Schmidt, 1875, pl. 26, figs 65,66 ) as synonyms of $A$. cymbelloides Grunow. Moreover, other forms superficially resembling A. ventricosa but published as $A$. cymbelloides (Schmidt, 1875, pl. 25, figs 10, 14) were also determined by Cleve (1895) as belonging to A. angusta (see also under Seminavis robusta). Adding to this confusion, the species shown in Schmidt (1875), pl. 25, fig. 15, was identified as $A$. angusta Ehrenberg (non Gregory) var. gracilenta Grunow. Ehrenberg (1854, p. 37) did indeed mention the name $A$. angusta, but gave no formal description or drawing, so that this was a nomen nudum. According to Mills (1933) and Van Landingham (1967), Ehrenberg gave a description in 1875 but this name is predated by Gregory's and is therefore illegitimate. Subsequent authors have adopted Cleve's treatment of these species (with the exception of Van Heurck, 1896), though often with considerable variation in the descriptions and measurements (Peragallo \& Peragallo, 1897-1908; Karsten, 1899; Skvortzow, 1927, $1932 a-d$; Brockmann, 1950; Cleve-Euler, 1953; Hustedt, 1955; Simonsen, 1962, 1974; ProshkinaLavrenko, 1963; Cholnoky, 1960; Giffen, 1963, 1976; Ricard, 1977, 1987; Montgomery, 1978; Navarro, $1982 a, b$; John, 1983; Jin et al., 1985; Foged, 1987; Kuylenstierna, 1989; Witkowski, 1994; Pankow, 1990; Metzeltin \& Witkowski, 1996). Through their figures, descriptions and references, mainly to the work of Cleve and Schmidt, these authors clearly indicated their concept of these species. A notable exception is that of Archibald (1983), who noticed the ambiguities and inaccuracies in the literature and admitted that his concept of $A$. angusta (and that of Cholnoky) was probably wrong.

Amphora ventricosa was resurrected as an independent taxon by Hendey $(1951,1958,1964)$, but 
the name was sometimes assigned to individuals having only a superficial resemblance to the original species. On two occasions, for example, it was applied to specimens with considerably higher stria densities (18-20 in $10 \mu \mathrm{m}$ in Hendey 1951, p. 70, pl. 9 , fig. 6 ; 1964, p. 269, pl. 38, fig. 12) and in one with more or less the normal value (10 in $10 \mu \mathrm{m}$ in Hendey, 1958, p. 75, no illustration). In 1973, Hendey decided that the illustration of $A$. angusta that he had given in 1964 was actually of $A$. ventricosa. The tendency to keep $A$. angusta and $A$. ventricosa separate seems to have been adopted by most recent authors, but while $A$. angusta is rarely reported, it is even more infrequently illustrated, and the scarce data regarding its morphology clearly indicate that the species found does not bear any relation to the original taxon (Giffen, 1963; John, 1983; Navarro, 1982 a; Foged, 1987; Ricard, 1987; Pankow, 1990; Witkowski, 1994; Metzeltin \& Witkowski, 1996). On the other hand, the name A. ventricosa has been used indiscriminately for a variety of different morphotypes (John, 1983, 1990; Coste \& Ricard, 1990; Foged, 1975, 1978, 1984, 1986; Park, 1992). A further consequence of the misinterpretation of the original $A$. angusta and $A$. ventricosa during the last 140 years has been the description of numerous unrelated taxa as varieties of A. angusta (Van Landingham, 1967).

From the preceding account and a literature survey, it is apparent that several different species are involved. With the exception of the original A. angusta, none of them belongs to Amphora, but to Seminavis D. G. Mann (in Round et al., 1990). This genus was erected to accommodate species previously classified in Amphora that possess uniseriate striae with slit-like areolae, as in Navicula Bory sensu stricto (Cox, 1999; Mann, 1989a); two girdleappressed plastids of unequal size; and a number of distinct ultrastructural characters of the areolae, raphe and girdle (Round et al., 1990). The type species selected for the new genus was $S$. gracilenta (Grunow ex A. Schmidt) D. G. Mann (= Amphora angusta var. gracilenta), which was chosen because of the uncertainties in the taxonomy of Amphora angusta and $A$. ventricosa that we have described. The only other species transferred by Round et al. (1990) was Amphora cymbelloides.

Seminavis corresponds closely to Cleve's (1895) subgenus Cymbamphora, which was erected for diatoms with amphoroid symmetry (extreme dorsiventrality) that 'have great resemblance to $\mathrm{Cym}$ bella, but not distinctly punctate striae' (Cleve, 1895) and girdle bands without obvious structure. Cleve considered Amphora to be a heterogeneous collection of genera, each related to a different genus of naviculoid diatoms, but found it impossible to identify a naviculoid equivalent for Cymbamphora. Mereschkowsky (1902-3) suggested that the closest relative was Caloneis Cleve, but ultrastructure and plastid characteristics clearly link Seminavis to Navicula sensu stricto and its allies, which include Rhoikoneis and Pseudogomphonema (Round et al., 1990; and see Discussion). This relationship was also detected independently by Sullivan (1990).

More recently, after examination of specimens found in Brazil, Garcia-Baptista (1993) made the combination Seminavis ventricosa (Gregory) Garcia-Baptista. Although the published LM and SEM photographs show only parts of the valve structure and are somewhat indistinct, it is likely that her specimens do indeed belong to Seminavis, but they bear little resemblance to A. ventricosa Gregory and cannot be classified as the same species. Garcia-Baptista's new combination is valid but must be applied to the species we illustrate here, not to the Brazilian diatom, for which a new name may be needed.

\section{Amphora angusta Gregory 1857}

Gregory (1857, p. 510, fig. 66) described and illustrated Amphora angusta as a 'form nearly rectangular, or rather linear-elliptic, narrow, truncated at the ends, so as to form a slender and somewhat elegant barrel shape. The inner curvelines arise in each half or valve from the outer angle, and meet in a nodule situated half-way across the valve. Both valves are transversely striated across, up to the narrow rectangular space in the middle. Length $0.0015^{\prime \prime}[=38 \mu \mathrm{m}]$; breadth of entire frustule $0.0004^{\prime \prime}[=10 \cdot 2 \mu \mathrm{m}]$. Striae fine, about 44 in $0 \cdot 001^{\prime \prime}$ [ $=17 \cdot 3$ in $10 \mu \mathrm{m}$ ]'. This morphology does not bear any resemblance to that of $A$. ventricosa given by Gregory in the same paper (p. 511), and it is difficult to understand how the two species could ever have been confused. Neither the shape of the frustule or valve, the position and shape of the raphe, nor the stria densities agree in the two forms (see also under $A$. ventricosa).

Slides 3289, 3291 and 3297 of Greville's collection (BM) have three Maltwood Finder references for A. angusta. The references on slides 3291 and 3289 correspond to individuals that agree more or less with Gregory's concept for this species. The frustule found in slide 3291 (Fig. 1) exhibits dimensions (42 $\mu \mathrm{m}$ long, $11 \mu \mathrm{m}$ wide) that correspond to Greville's original drawing. The stria density on the dorsal side of the valve is $16.8-17 \cdot 2$ in $10 \mu \mathrm{m}$, depending on the site of measurement, while the ventral stria density is slightly less, being $15 \cdot 5-16$ in $10 \mu \mathrm{m}$. The shape of the valve and especially the almost straight ventral margin, the unornamented structure of the girdle and the more or less rectangular central area also correspond to the original description and drawing. The specimen on slide 


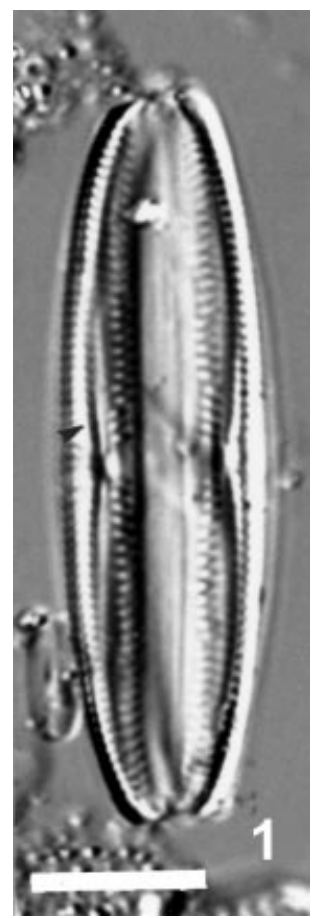

Fig. 1. Light micrograph (DIC) of the lectotype of Amphora angusta Gregory, located via a Maltwood Finder reference on slide BM 3291, showing the barrel-shaped frustule with the unornamented girdle and the arching raphe branches (arrowhead). Scale bar represents $10 \mu \mathrm{m}$.

3289 has basically the same morphology but is considerably shorter and has a higher stria density $(21 \mu \mathrm{m}, c .20$ striae in $10 \mu \mathrm{m})$. Although it is not a complete frustule and therefore does not resemble the original drawing so closely, it is clearly the same species. By contrast, the Finder reference on slide 3297 corresponds to a single valve that probably belongs to a different species. Under low magnification this specimen has a gross resemblance to A. angusta, but the shape of the valve, especially the ventral margin, which is convex with rounded swellings at the centre and poles, distinguishes this form from true $A$. angusta. Furthermore, there is what seems to be a longitudinal interruption of the striae (possibly a fold of the valve surface) in the mid-dorsal portion of the valve; this is not observed in the other marked specimens, which also differ in ventral stria orientation and densities. In dimensions and striation the BM 3297 specimen, which we will refer to as $A$. cf. angusta, resembles $A$. angusta ( $29.5 \mu \mathrm{m}$ length, $c .18 .5$ striae in $10 \mu \mathrm{m}$ ). There are several individuals of both forms on the BM slides, besides those identified by Finder references, including some whole specimens of $A$. cf. angusta. These differ from $A$. angusta in shape: the length to width ratio is smaller and the frustules are more expanded laterally.

No other form resembling the drawing and description of $A$. angusta could be found in the vicinity of the references on Greville's slides. Thus we are confident that either or both types of valve

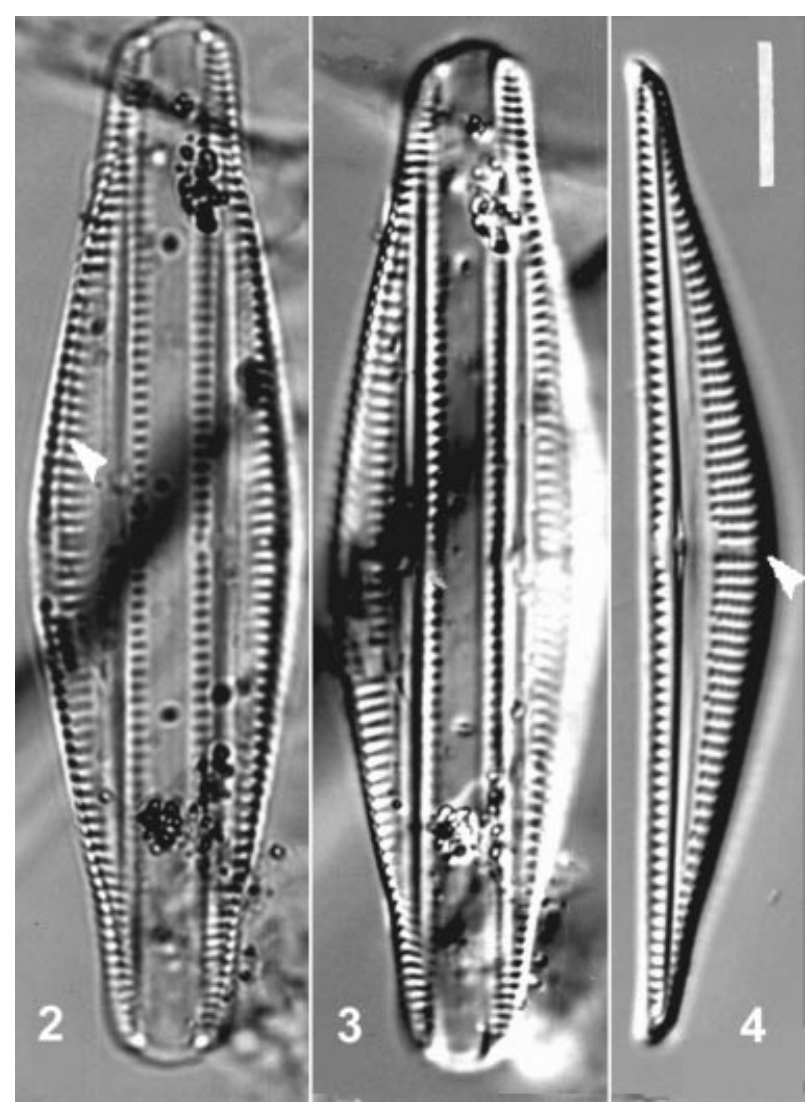

Figs 2-4. Light micrographs of Seminavis ventricosa (Fig. 2: BF optics, Figs 3, 4: DIC). Figs 2, 3. Lectotype, slide BM 1438, engraved ring 3. Note the straight raphe and the shadow line (Fig. 2, arrowhead) under the dorsal striae that indicates the underlying chambered structure of the valve. Fig. 4. Recent subtidal material from Loch Goil, west Scotland (RBGE slide E344/1), showing the dorsal widening of the axial area, the missing middle stria (arrowhead) and the deflecting central raphe slits. Scale bar represents $10 \mu \mathrm{m}$.

described above represent what Gregory meant by $A$. angusta, and we can choose which form to select as the type of $A$. angusta. Based especially on the overall shape of the frustule, we designate the individual found on BM slide 3291, England Finder Reference L32/0 (near the 2-4 boundary), as the lectotype (Fig. 1). The selection of this lectotype, though fully justified under the International Code of Botanical Nomenclature (Greuter et al., 2000), could be argued to be undesirable, since it does not fulfil one of the main aims of ICBN, viz. to provide stability. However, although $A$. angusta has almost always been interpreted wrongly, studies of the marine benthos are in their infancy and we consider that the balance of advantage lies with a return to Gregory's concept, rather than with an attempt to conserve A. angusta with a new type, as a taxon in Seminavis. Regardless of the true identity of Ehrenberg's $A$. angusta, his species was formally described and figured much later (in 1875) than Gregory's Amphora angusta (in 1857) and so is illegitimate. 


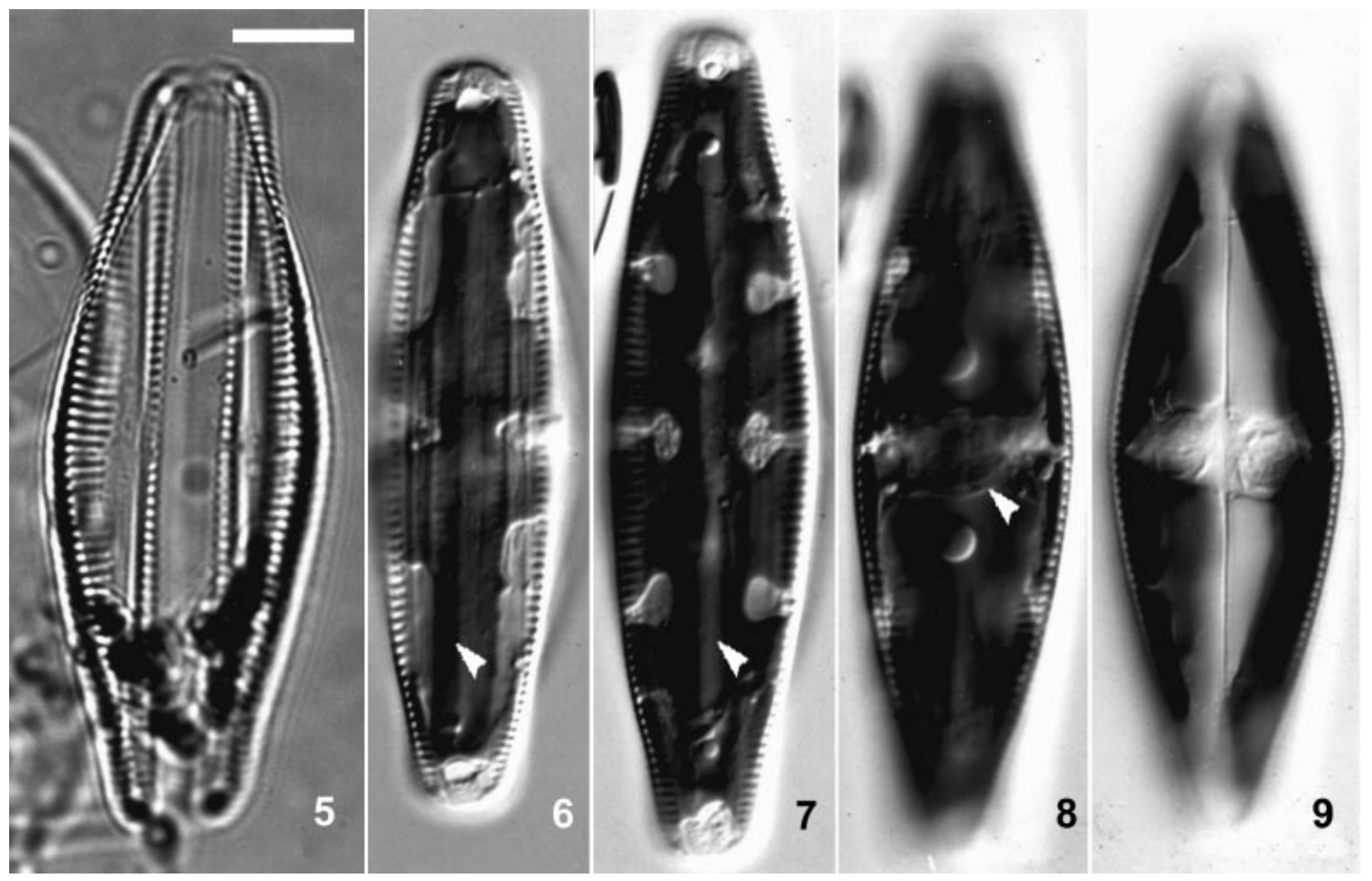

Figs 5-9. Light micrographs of Seminavis ventricosa (BF optics). Fig. 5. Isotype on slide BM 1438, engraved ring 4.

Figs 6-9. Fresh material from Loch Goil, showing the arrangement of the chloroplasts, the bar-like pyrenoid (Figs 6, 7, arrowheads), nucleus (Fig. 8, arrowhead) and cell division (Fig. 9). In Fig. 9, the plastids lie against the epivalves of the new daughter cells and have divided transversely (visible at the centre of the right-hand cell), so that each cell contains two plastids, one either side of the median transapical plane; note the central nuclei with flanking polar vacuoles. Scale bar represents $10 \mu \mathrm{m}$.

Our observations from Greville's slides yield the following emended description.

Amphora angusta Gregory 1857 (p. 510, fig. 66)

Fig. 1

Lectotype (designated here): BM Slide 3291, England Finder Reference L32/0 (near the 2-4 boundary)

Frustules linear-elliptical, slender, barrel-shaped, 21-43 $\mu \mathrm{m}$ long, 9-11 $\mu \mathrm{m}$ wide. Valves linear with obtusely rounded apices, with a smoothly convex dorsal margin and a straight ventral margin. Raphe branches arched. Central area small, rectangular, a little wider on the ventral side. Dorsal striae more or less parallel, $16 \cdot 5-20$ in $10 \mu \mathrm{m}$; ventral striae 15-18 in $10 \mu \mathrm{m}$.

\section{Amphora ventricosa Gregory 1857}

There are three slides bearing ringed specimens of A. ventricosa in the Greville Collection (BM 1223, 1438,2518 ) and one with two Maltwood Finder references (BM 3291). With the exception of slide 1223, all come from dredgings near the Isle of Arran in 1856, which are the locality and date mentioned by Gregory (1857). Slide 1223 is marked 'Arran Gregory 57' and thus probably comes from a later collection, for which it is not known who is responsible. The slide with Maltwood Finder references (\#3291) carries a different species to that represented by the ringed specimens. Two forms of $A$. ventricosa can also be detected in the drawings by Greville that accompany the 1857 publication, where figs $68 \mathrm{a}$ and c (corresponding to the ringed specimens) have little resemblance to fig. $68 \mathrm{~b}$ (corresponding to the Maltwood Finder specimens). The description given by Gregory is 'form linearlanceolate, with obtuse apices, more or less expanded in the middle. Valve long, very slender, arcuate, with acute ends, marked with somewhat coarse transverse striae. Length from 0.0023" to $0.0035^{\prime \prime}[=58.4-88.9 \mu \mathrm{m}]$; greatest breadth at the expansion in the middle $0.0005^{\prime \prime}$ to $0.0008^{\prime \prime}$ $[=12 \cdot 7-20 \cdot 3 \mu \mathrm{m}]$. Inner line generally obscure, but in some cases clearly visible. They arise from the inner angle of the valve, pass rapidly across, and, as shown in fig. $68 \mathrm{~b}$, sometimes extend beyond the outer margin; then suddenly bend inwards to meet the obscure nodule near the inner margin. Rectangular middle space narrow. Striae strong, about 22 in $0.001^{\prime \prime}$ [c. 8.7 in $10 \mu \mathrm{m}$; conspicuous'. This 


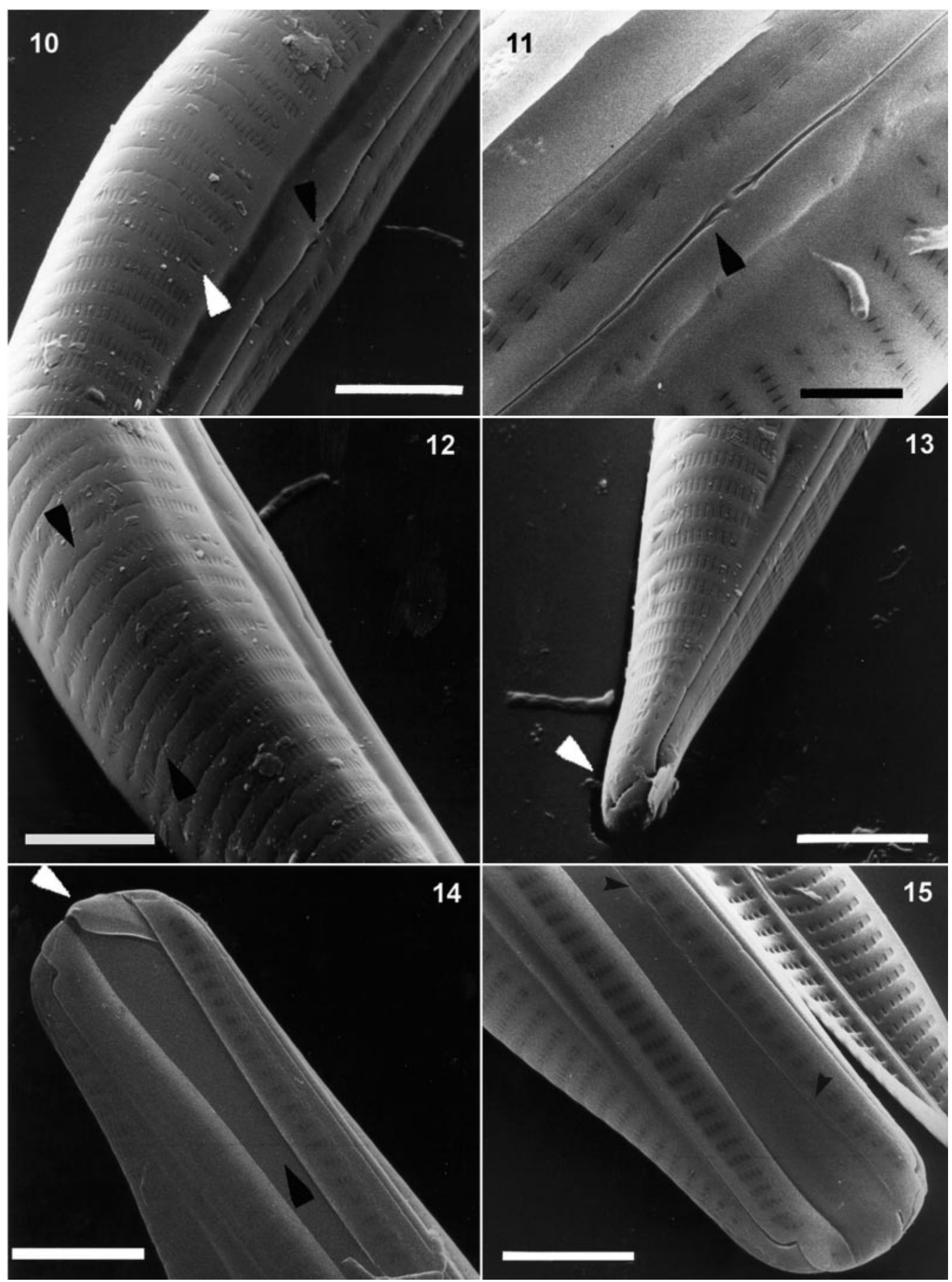

Figs 10-15. External views of Seminavis ventricosa, SEM (recent specimens from Loch Goil, west Scotland). Fig. 10. External view of valve mid-section, showing the central raphe endings deflecting to the ventral side and the alternating central pores (black arrowhead). Note also the disoriented slit-like areolae (white arrowhead) and the deep groove running along the axial area. Fig. 11. Higher magnification of the central area, showing the central raphe endings running within a gorge (arrowhead) on the thickened central nodule. Fig. 12. External view of the deep dorsal mantle. Note the absence of a 
description fits fig. 68b rather well, although Gregory also includes comments that apply to the morphology of the second form (p. 511 and addendum) without distinguishing them. Any of the specimens collected in 1856, of either morphotype, can therefore be designated as the type of $A$. ventricosa; we choose the ringed individuals since they are more easily located and show the intentions of the author unambiguously. The specimens marked with Finder references on BM 3291 clearly belong to a different species, which has not previously been described. Neither of the morphotypes on Greville's slides corresponds to the diatom studied by Garcia-Baptista (1993), when she made the new combination Seminavis ventricosa. An emended description is necessary.

\section{Seminavis ventricosa (Gregory) Garcia-Baptista}

Figs 2-21

BASIONYM: Amphora ventricosa Gregory 1857, partim., non Seminavis ventricosa sensu GarciaBaptista 1993, p. 49, figs 139, 230-232

LECTOTYPE (designated here): BM 1438, engraved ring 3 (Figs 2, 3)

ISOTYPE: BM 1438, engraved ring 4 (Fig. 5)

Frustules lanceolate with evidently drawn-out apices. Valves semi-lanceolate, 51.5-101 $\mu \mathrm{m}$ long, 6-10 $\mu$ m wide, with a convex dorsal margin and a straight or only very slightly concave ventral margin (Figs 2-7). The dorsal side of the axial area is typically wider than the ventral. The valve face is not flat externally and is dominated by a deep groove separating the heavily silicified sternum from the gibbous dorsal side of the valve. The dorsal mantle is deep with no distinct boundary towards the valve face (Figs 12, 13).

The raphe is parallel and close to the ventral margin (Figs 4, 5, 10, 13), with almost straight branches that are deflected ventrally at the centre, and with central pores pointing in opposite directions (Figs 4, 10, 11). The central part of the raphe enters a narrow 'gorge' before opening out again near the raphe endings (Figs 10,11). The apical raphe endings are hooked to the dorsal side (Figs 4, 13). Internally the raphe runs on a rib, which is turned over towards the dorsal side (so that the slit can be seen only by viewing at an oblique angle from the dorsal margin) and twists into the vertical position only at the centre and poles (Figs 17, 20, 21). The central raphe slits are based on a small, elongated nodule (Figs 20, 21), while apically the raphe ends at a small, ventrally bent helictoglossa (Fig. 17).

The dorsal striae are weakly radial, $10-12.8$ in $10 \mu \mathrm{m}$; the middle stria is usually missing - at least on the adaxial side - or reduced, not reaching the axial area. The ventral striae are 10-12.1 in $10 \mu \mathrm{m}$ and are approximately the same size along the whole length of the valve. The striae are composed of longitudinally elongate, densely arranged areolae (sometimes resolved under LM only with BF optics) that commonly change their orientation and turn vertically or at an angle to the apical axis. Thus, stria width fluctuates and is frequently reduced to that of a single transapically oriented areola (Figs 4, $5,10-13)$. The terminal areola of some dorsal striae is occasionally double and stria discontinuities are frequently observed. The internal areola openings are also slit-like and have the same orientation as externally (Fig. 19).

The axial sternum is heavily silicified with a thickened central nodule, which is a little expanded on the dorsal side. The dorsal side of the axial area is wider internally than externally and combines with the transapical costae to form small chambers at the adaxial ends of the striae (cf. the alveoli of Pinnularia: Round et al., 1990), which sometimes open to the cell interior (Fig. 21). This can be detected in LM and SEM by the continuation of the dorsal striae and frets into the axial area, where they appear as shadows (Figs 2, 4, 18, 20, 21). Chambering is also evident on the ventral side, especially in the middle part of the valve, where the slit-like areolae open into a small compartment that has a single round opening to the valve interior (Figs 18-21). A single row of simple pores is present beyond the helictoglossa at both valve apices (Figs $15,17)$.

The girdle is composed of three plain, open bands. The first band is wide. The second band fills the gap between its open ends and is only a short segment (Figs 14, 15). The third element is extremely narrow and delicate and we have been unable to determine its structure fully (Fig. 15).

We found living material of $S$. ventricosa in Loch Goil, Argyll, western Scotland. As in other Seminavis species we have studied, there are two plastids per cell, one lying against either side of the girdle, as in Navicula sensu stricto. The plastids also resemble those of Navicula in having a single bar-like pyrenoid, which runs the length of the plastid along its central line (Figs 6, 7). The plastid margin is

definite boundary to the valve face and the discontinuities and change of orientation of the transverse striae (arrowheads). Fig. 13. External view of the pole with dorsally hooked apical raphe slit (arrowhead). Fig. 14. Fine structure of the girdle, showing the unornamented main girdle band (black arrowhead) and the apical ligula (white arrowhead). Fig. 15. Other end of the same frustule, showing the main (first) girdle band and the very narrow third element of the girdle (arrowheads).

Scale bars represent $2 \mu \mathrm{m}$ (Fig. 11), $4 \mu \mathrm{m}$ (Figs 10, 12, 13) or $5 \mu \mathrm{m}$ (Figs 14, 15). 


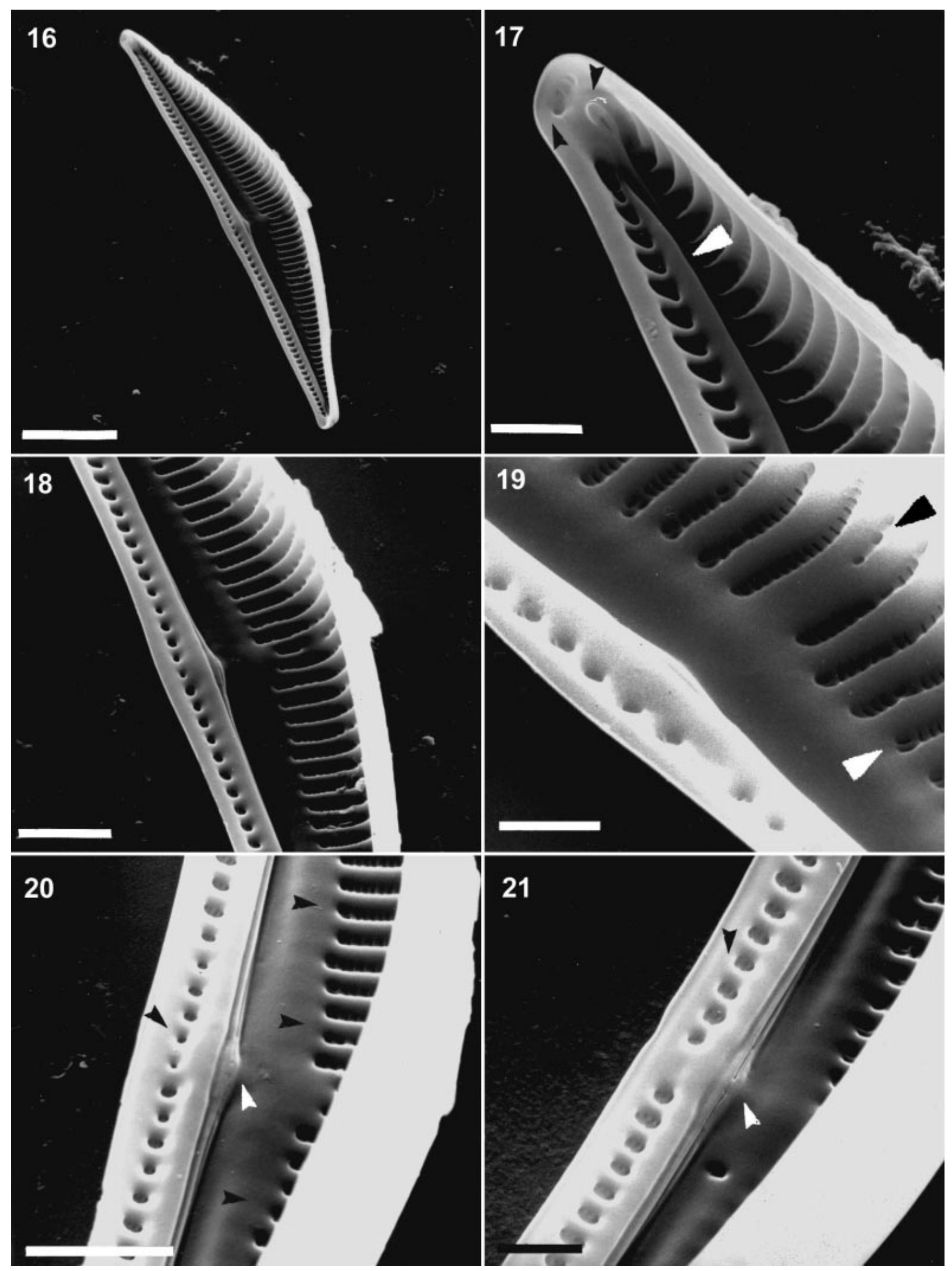

Figs 16-21. Internal views of Seminavis ventricosa under SEM (recent specimens from Loch Goil, west Scotland). Fig. 16. General view of the valve's interior, showing the shape of the valve and position of the raphe. Fig. 17. Internal view of the pole, showing the bent rib on which the raphe runs (white arrowhead), the terminal helictoglossa and the apical chamber with internal openings of the apical simple pores (black arrowheads). Fig. 18. Internal central portion of the valve; note the interrupted middle stria on the dorsal side and the prominent central nodule. Fig. 19. Higher magnification of valve's mid section, showing the short middle dorsal stria with disoriented areolae (black arrowhead) and the double areolae at the adaxial side (white arrowhead). Figs 20, 21. Note the weak chambering of the valve on both dorsal and ventral sides (black 


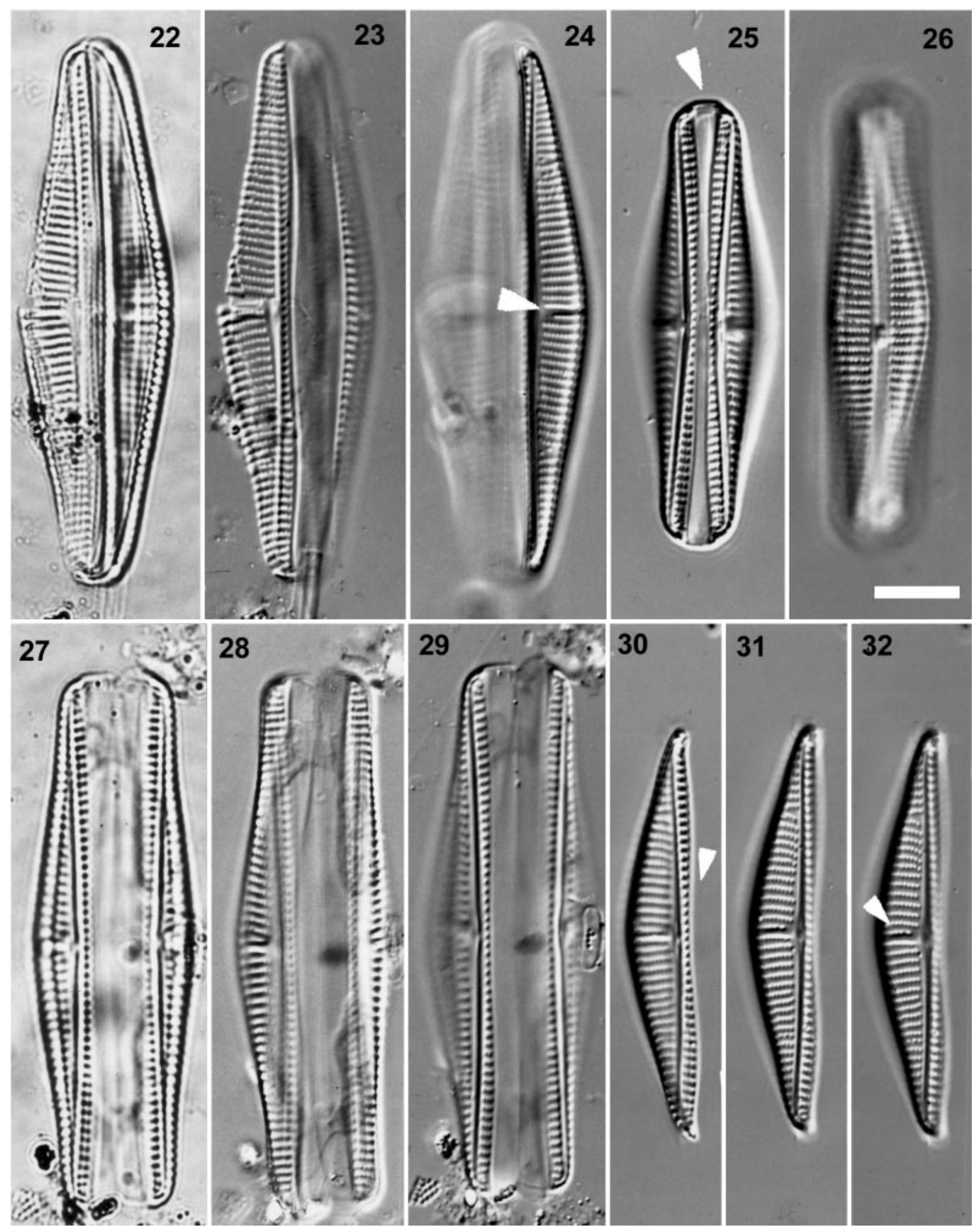

Figs 22-32. Light micrographs of Seminavis arranensis (Figs 22, 27, BF optics; Figs 23-26, 28-32, DIC). Figs 22-24. Holotype on slide BM 3291 (Maltwood Finder reference $\frac{35}{24}$ ). Note the converging branches of the raphe and the robust central transapical rib (arrowhead). Figs 25, 26. Recent material collected from Loch Goil (RBGE slide M1/1), showing the ventral and dorsal sides of the frustule. Note the two unornamented girdle elements (ligula at the top, arrowhead) and position of the raphe. Figs 27-29. Isotype on slide BM 3291 (Maltwood Finder reference $\frac{22}{19}$ ). Figs $30-32$. Recent material at different foci (Loch Goil slide M1/1). Note the undulating ventral margin and the thickened transapical rib on the middorsal side (arrowhead). Scale bar represents $10 \mu \mathrm{m}$. 


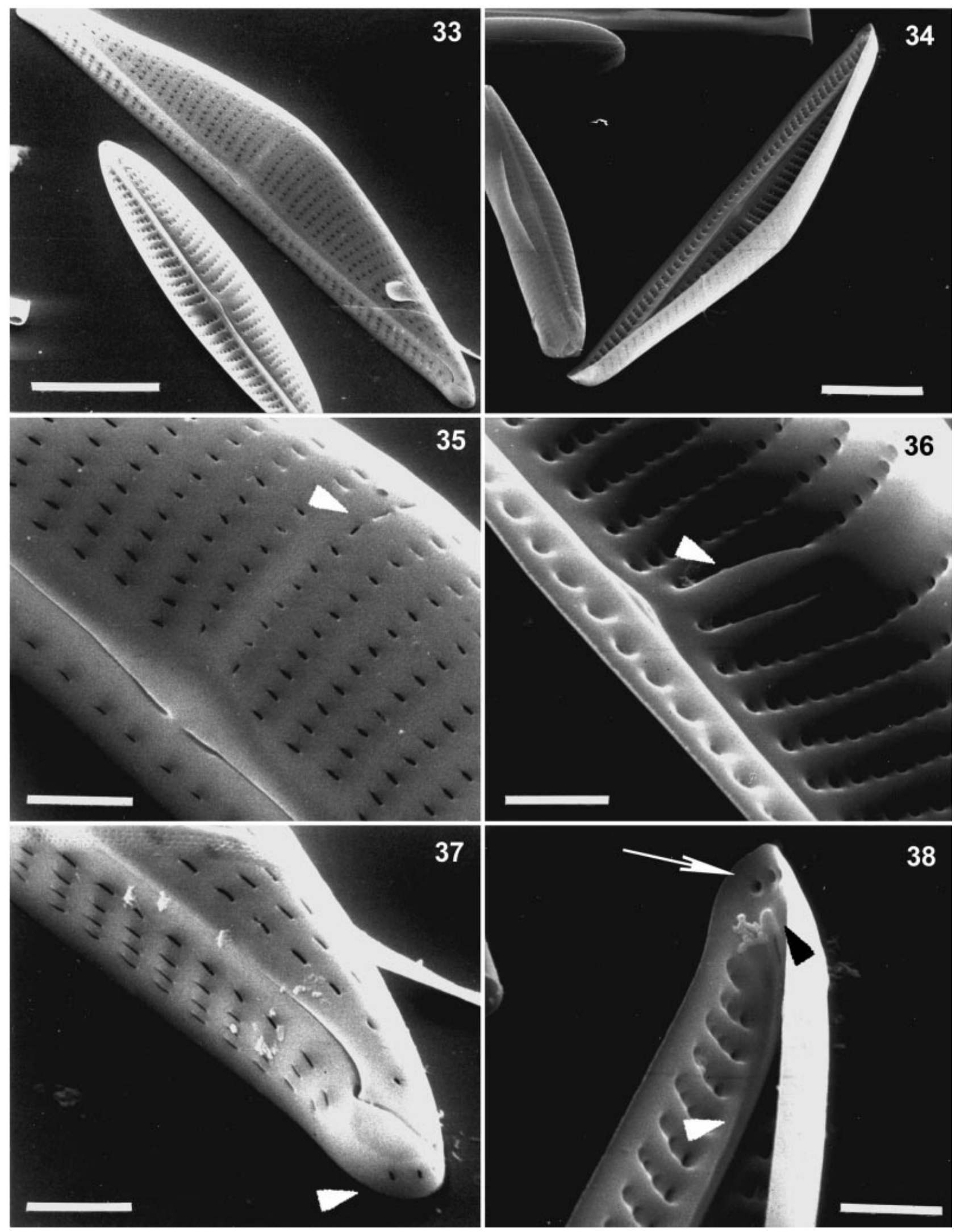

Figs 33-38. Fine structure of Seminavis arranensis. Fig. 33. External view showing the shape of the valve and position of the raphe. Note the progressively shorter length of the ventral striae towards the central area. Fig. 34 . Internal view of the valve showing the rib on which the raphe runs. Note the deep dorsal mantle and the weak chambering of the middle ventral areolae (see also Fig. 36). Fig. 35. Detail of the external mid-portion of the valve. The central raphe endings deflect to the ventral side; the areolae are slit-like openings, frequently disoriented in the middle striae (arrowhead); and the deep dorsal mantle is not clearly differentiated from the valve face. Fig. 36. Detail of the internal mid-portion of the valve. The internal areola openings are elliptical and the middle transapical rib is distinctly robust (arrowhead). The openings of the midventral striae are deep in the cell wall and not at the surface, which is indicative of a weak chambering structure as seen in 
indented narrowly at the centre and again, often more broadly, roughly halfway from centre to poles (Figs 6,7). Similar plastid morphology was illustrated by Cleve (1895, p. 134), although it is impossible to be sure whether he was drawing the same taxon. Mereschkowsky (1901) showed a simpler plastid morphology, with only a central constriction. The two plastids of $S$. ventricosa are apparently unequal in size, corresponding to the difference in width between the two sides of the girdle.

At cell division, the plastids are translocated bodily from the girdle laterally to the valves (Fig. 8), where they divide transversely by constriction (not illustrated, because of the continual movement of dividing cells). At the same time the pyrenoid is bisected. Then mitosis and cytokinesis occur, so that initially each daughter cell possesses two plastids lying against the epitheca (Fig. 9), one in each polar half of the cell (as in the quite unrelated genus Nitzschia). During valve formation, the plastids are translocated diagonally in opposite directions into their final positions on the girdle, in coordinated movements resembling the rotations of Sellaphora Mereschkowsky and Craticula Grunow plastids (Mann, 1989a; Mann \& Stickle, 1991). Rotation takes place in the same direction relative to the epitheca of each daughter cell. After plastid division and during translocation from the valves to the girdle, the plastids have a simple morphology; the characteristic constrictions of the interphase chloroplast develop only after the plastids have attained their final positions against the girdle.

The nucleus lies in a small central bridge of cytoplasm during interphase, between two vacuoles (Fig. 8). A single nucleolus is present. Since the cells remain motile during cell division (as in many Navicula sensu stricto species), and since we only observed living cells, it was impossible to determine the exact position of the nucleus at cell division. However, given the constant dorsal curvature of the raphe at the poles, it is likely that the mitotic nucleus lies against the ventral side of the girdle: see Mann (1983), Mann \& Stickle (1988) and Round et al. $(1990$, p. 80) for discussion of nuclear division-cell symmetry relationships.

This form has scarcely ever been unambiguously recorded since 1857. In Schmidt (1875), pl. 25, fig. 5, there is a specimen resembling this species that was left unnamed, with only an indication of the locality 'Hvidingsoe', which suggests that this comes from the German North Sea expedition of 1872 (Schmidt, 1874). One of the few remaining slides from this locality is BRM 272/30 in the Hustedt collection at Bremerhaven, which does indeed contain a single valve of this $A$. ventricosa morphotype. According to Cleve (1895), the form illustrated by Schmidt is intermediate between $A$. angusta vars ventricosa and eulensteinii ( = Amphora eulensteinii Grunow), but the valve we found is in all respects identical to Greville's ringed specimens of $A$. ventricosa. Park (1992), working in Loch Goil, included both morphotypes (and one more: see under $S$. macilenta) presented here under $A$. ventricosa.

Seminavis arranensis Danielidis \& D. G. Mann, sp. nov.

Figs 22-38

Amphora ventricosa Gregory, pro parte (Gregory, 1857, fig. 68b)

Holotype: BM 3291, Maltwood Finder $\frac{35}{24}$ (Figs 22-24)

Isotype: BM 3291, Maltwood Finder $\frac{22}{19}$. (Figs 27, 28)

OTHER AUTHENTICATED SPECIMEN: Loch Goil slide M1/1 (E), collected April 1988, England Finder Reference K46/4 (near the 4-3 boundary) (Figs 30-32)

Frustula lanceolata. Valvae semilanceolatae, 42 $85 \mu \mathrm{m}$ longae, $6-9 \mu \mathrm{m}$ latae, margine dorsali leniter convexo, margine ventrali plusminusve laeviter undulato ad centrum concavo ad positionem inter centrum polosque mediam convexo. Frons fere plana, depressione minimi proxime super area centrali interdum instructa; limbus ventralis a fronte haud distinctus; limbus dorsalis profundus in frontem gradatim transiens. Pars dorsalis areae axiali quam pars ventralis latior, in aream centralem parvam expansa. Raphe introrsum arcuata centrum versus prope marginem ventralem accedens. Extrema centralia raphis ventraliter deflexa. Striae nec dorsales nec ventrales non loculatae, dorsalibus radialibus $8-10$ in $10 \mu \mathrm{m}$. A $S$. ventricosa area axiali dorsaliter minus manifesta, raphe non recta, striis minus confertis differt.

Frustules lanceolate with pronounced apices. Valves semi-lanceolate, $42-85 \mu \mathrm{m}$ long, $6-9 \mu \mathrm{m}$ wide. Dorsal margin gently convex; ventral margin more or less smoothly undulate, with a concave mid-section and a convex outline at mid-distance to the poles (Figs 22-32). Valve face almost flat, or sometimes with a very small depression just above the central area on the dorsal side (as seen in SEM;

other species of Seminavis. Fig. 37. External view of the valve pole. Note the dorsally hooked apical raphe fissures and the simple row of apical pores (arrowhead). Fig. 38. Internal view of the pole showing the twisted raphe rib (black arrowhead), the terminal helictoglossa (white arrowhead) and the internal openings of the simple apical pores (white arrow). Scale bars represent $2 \mu \mathrm{m}$ (Figs 35-38) or $10 \mu \mathrm{m}$ (Figs 33, 34). 


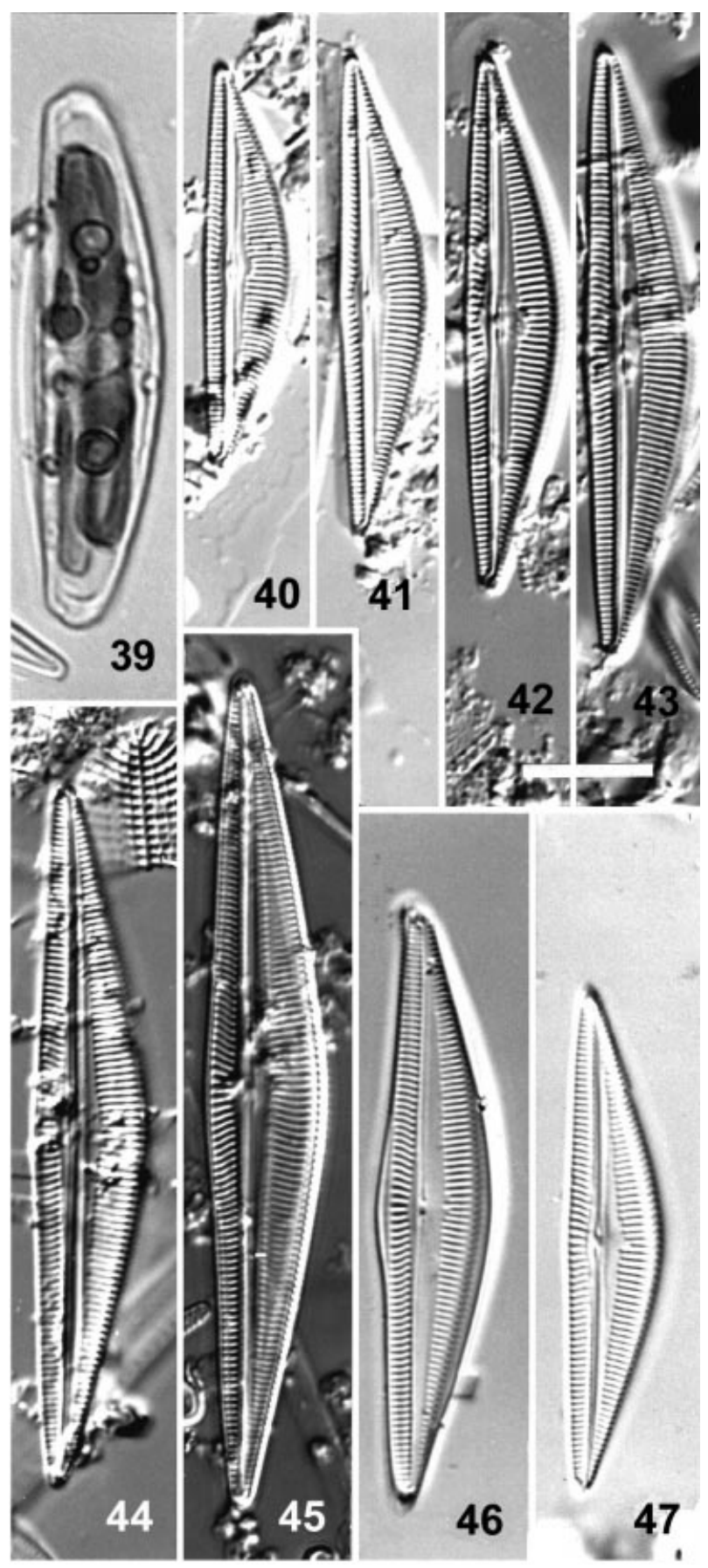

Figs 39-47. Light micrographs of Seminavis robusta (Fig. 39, BF optics; Figs 40-44, 46, 47, DIC; Fig. 45. PhC). Fig. 39. Fresh material from the Messolonghi lagoon, showing a side view of the chloroplast. Figs 40-45. Size range of valves from Messolonghi. Fig. 42. Holotype, on slide ADH 300/1. Figs 46, 47. Specimens from Java (slide no. 147, Cleve \& Möller exsiccata set, Adams collection, BM). Scale bar represents $10 \mu \mathrm{m}$.

Figs 33, 35). Ventral mantle indistinguishable from valve face; dorsal mantle deep, merging imperceptibly into the valve face (Figs 33, 35). Axial area distinctly wider on the dorsal side but not as prominent as in $S$. ventricosa, expanding to form a small central area (Figs 24, 25, 31).

The raphe is bowed inwards in girdle view, becoming close to the ventral side at the centre; it is not straight as in S. ventricosa. This layout of the raphe was noted by Gregory (1857) and can also be seen in one of his illustrations (fig. 68b). The central raphe endings are ventrally deflected (Figs 25, 27, $31,33,35)$. The polar raphe endings are hooked to the dorsal side (Figs 33, 37). Internally the raphe is located on a longitudinal rib, which is bent over towards the dorsal side, as in S. ventricosa. The central nodule is a small elongate structure internally, with the raphe slits placed in the middle (Figs 34, 36, 38). The raphe ends apically in a small helictoglossa (Fig. 38).

The dorsal striae are radial, $8-10$ in $10 \mu \mathrm{m}$, and composed of fine but distinct areolae (in LM). The central transapical rib is more robust (again as seen in LM) and thickened internally (Figs 24, 25, 28, 31, $32,36)$. This also was illustrated by Gregory $(1857$, fig. 68b). The ventral striae are wider at the poles, getting noticeably shorter towards the middle of the valve (Figs 23, 25, 31, 33, 34). The striae are composed of loosely spaced linear areolae, which open internally via simple elliptical pores. Loss of orientation is present in some areolae of the central striae, especially in the adaxial area; these areolae seem not to penetrate through to the interior of the valve (Figs 35, 36).

There is a single row of simple apical pores beyond the helictoglossa at each end of the valve (Figs 33, 37, 38). There is no evident chambering on either the dorsal or the ventral side of the valve (Figs 34-36).

The girdle bands are plain and open. The wide first band and the segmental apical element, representing band 2, are easily distinguished (Fig. 25), but a narrow third band could not be observed in this case. The plastid morphology is unknown.

This form has rarely been reported since its original discovery by Gregory. When it has been found, it has usually been left unnamed or attributed to other species with a query (Peragallo \& Peragallo, 1897-1908, pl. 50, fig. 21 as 'A. inflata Greg.?'; Kuylenstierna, 1989, pl. 42, fig. 450 as 'Amphora sp.'). Hendey (1973, figs 21, 22) illustrated it from Porthleven, Cornwall, SW England, as A. ventricosa.

Seminavis robusta Danielidis \& D. G. Mann, sp. nov.

\section{Figs 39-53}

Holotype: ADH 250/1, England Finder Reference R42/1 (Fig. 43)

Frustula lanceolata vel rhombico-lanceolata, extremis plusminusve obtuse rotundatis. Valvae semilanceolatae, 34-68 $\mu \mathrm{m}$ longae, 6.5-9.5 $\mu \mathrm{m}$ latae, margine dorsali convexo, margini ventrali laevissime convexo interdum centraliter tumido, apprime cellularum majorum. Limbus ventralis haud dis- 

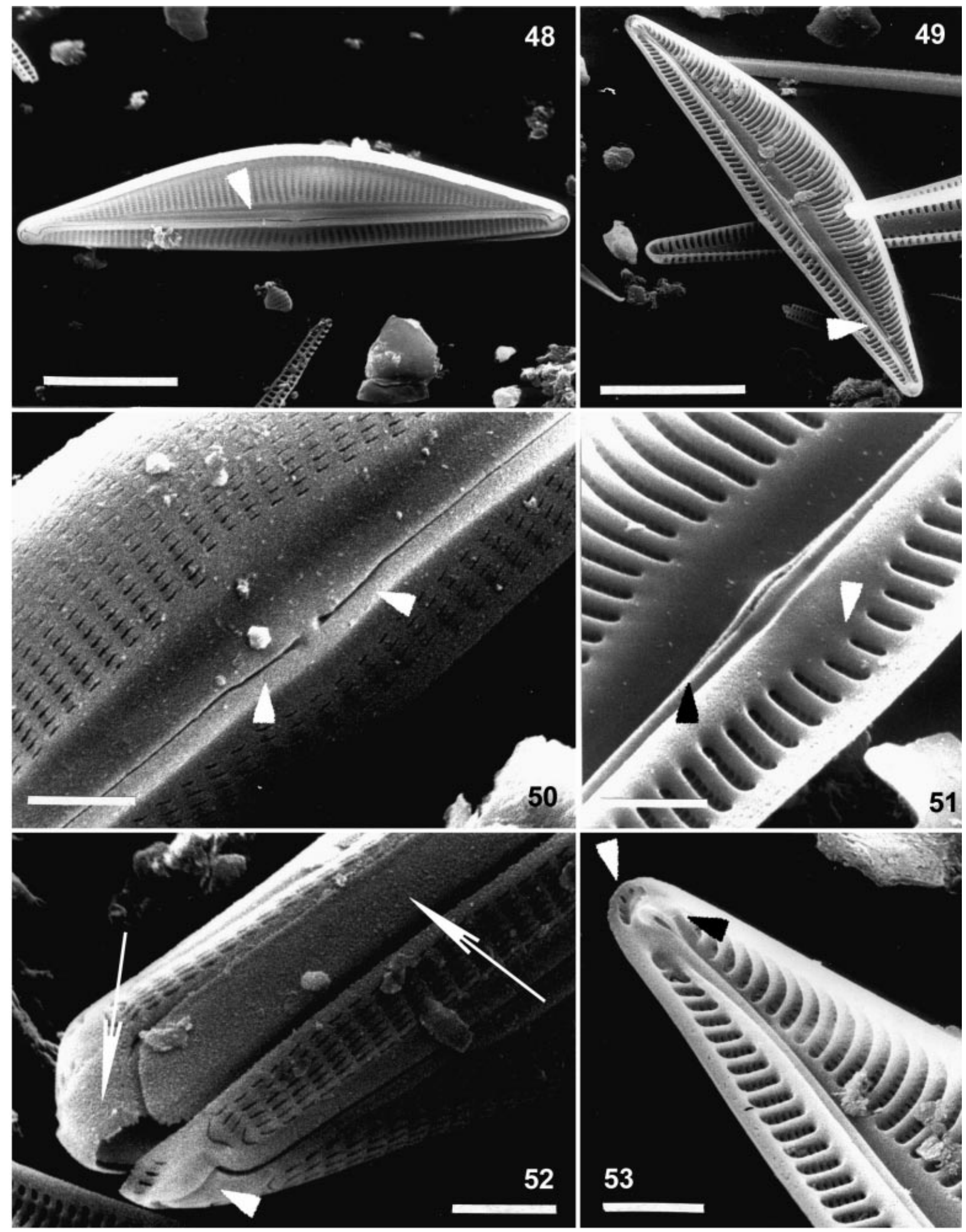

Figs 48-53. Fine structure of Seminavis robusta. Fig. 48. External view of the valve, showing the position and shape of the raphe as well as the groove on the dorsal side of the valve (arrowhead). Fig. 49. Internal view of the valve. Note the twisted rib on which the raphe runs (arrowhead). Fig. 50. Detail of the mid-portion of the valve, showing the ventral deflection of the central raphe endings (arrowheads) and the external slit-like areola openings. Fig. 51. Detail of the internal mid-section of the valve. Note the raphe rib (black arrowhead) and the apically expanded central nodule. Some chambering of the middle ventral areolae can been observed as a result of the ventral extension of the central area (white arrowhead). Fig. 52. Detail of the frustule's apical region, showing the unornamented main girdle band and ligula (arrows). Note the denser stria arrangement at the poles (compare with Fig. 50); the apical raphe fissures are dorsally hooked (white arrowhead). Fig. 53. Internal view of the pole, showing the twisted raphe rib, the terminal helictoglossa (black arrowhead) and the apical row of simple pores (white arrowhead). Scale bars represent $2 \mu \mathrm{m}$ (Figs 50-53) or $10 \mu \mathrm{m}$ (Figs 48, 49). 


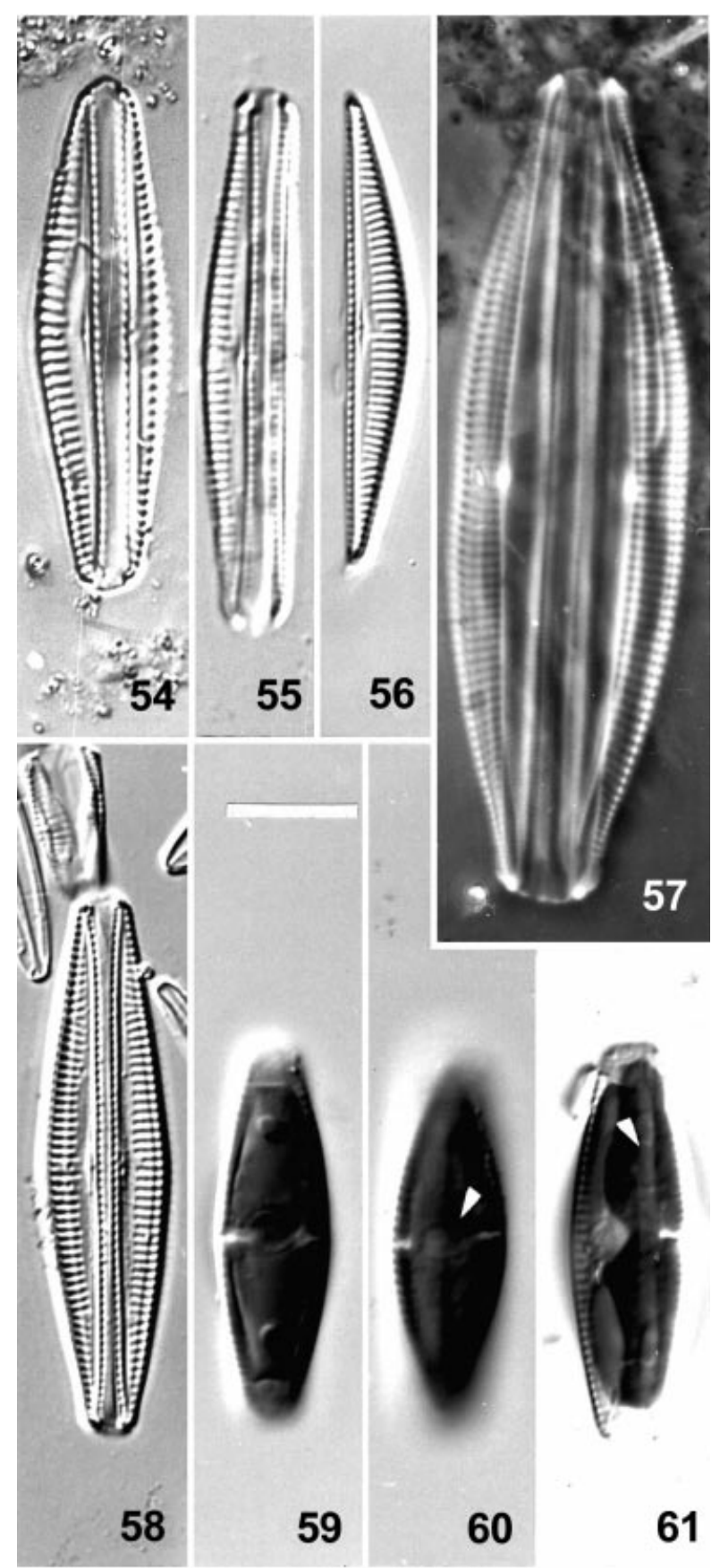

Figs 54-61. Light micrographs of Seminavis macilenta (Figs 54-56, 58-61, DIC; Fig. 61, PhC) and Amphora ergadensis (Fig. 57). Fig. 54. Isotype on slide BM 3291, England Finder Reference G33/3. Fig. 55. Lectotype, slide BM 3291, England Finder Reference M45/2. Figs 56, 58. Recent subtidal material from Loch Goil, west Scotland (RBGE slide M1/1). Fig. 57. Amphora ergadensis Gregory, slide BM 1362 engraved ring 4. Figs 59-61. Fresh material from Loch Goil showing the arrangement and shape of the chloroplasts, which have one midindentation (Figs 59, 61), the nucleus (Fig. 60, arrowhead) and the bar-like pyrenoid (Fig. 61, arrowhead). Scale bar represents $10 \mu \mathrm{m}$.

tinctus, limbus dorsalis profundus in frontem gradatim transiens. Pars dorsalis areae axiali quam pars ventralis multo latior; pars ventralis in aream rotundatam centraliter expansa; area axialis a fronte sulcis utrinque separata. Raphe recta, extremis centralibus ventraliter deflexis. Striae dorsales vix/non loculatae ad centrum radiatae, polos versus minus radiatae vel fere parallelae, $17-20.7$ in $10 \mu \mathrm{m}$; striae ventrales ad centrum loculatae (alveolatae) manifeste radiatae, $16-19 \cdot 3$ in $10 \mu \mathrm{m}$, sed polos versus simplices confertiores parallelae. A $S$. ventricosa striis confertioribus, margine ventrali convexo, area centrali ventrali rotundata differt.

Frustules lanceolate to rhombic-lanceolate, 34 $68 \mu \mathrm{m}$ long, with more or less obtusely rounded ends. Valves semi-lanceolate, $6 \cdot 5-9 \cdot 5 \mu \mathrm{m}$ wide, with convex dorsal and very slightly convex ventral margins. The ventral side of the valve sometimes exhibits a slight swelling in the middle, especially in larger individuals (Figs 40-45). A ventral mantle is almost undetectable, and the dorsal mantle is deep, but with no defined border between it and the valve face (Figs 50, 52). The axial area is much wider on the dorsal side, with a central roundish expansion on the ventral side. The gibbous axial area is separated from the more or less flat ventral side and the gibbous dorsal part by grooves, which in LM have the appearance of dark lines or areas running along either side of the raphe (Figs 40-45, $48,50,52)$.

The raphe is straight, running along the long axis of the valve. Externally the raphe branches are deflected ventrally at the centre and are hooked dorsally at the apices (Figs 41-43, 48, 50, 52). The internal raphe ridge is bent dorsally, as in other Seminavis species, bearing the central slits on a longitudinal thickening (Figs 49, 51, 53). The raphe ends apically in a small, ovate, and ventrally bent helictoglossa (Fig. 53). A single series of simple pores is present beyond the helictoglossa at both apices (Figs 52, 53).

The dorsal striae are radiate in the middle, $17-20 \cdot 7$ in $10 \mu \mathrm{m}$, but less so at the apices, where they are denser. The change in orientation takes place at the end of the wider part of the axial area, at the Voigt discontinuity (Figs 40, 43, 49, 52). The ventral striae are $16-19.3$ in $10 \mu \mathrm{m}$, distinctly radiate in the middle but much denser and parallel at the apices. The areolae have the typical Seminavis morphology, with slit-like external openings; anomalies in their orientation like those in the preceding species were never observed (Figs 48, 50, 52). Internally the valve structure resembles that of all other Seminavis species presented here. The costae are strong and the frets between them are weak, while the areola openings are again slit-like (Figs 49, 51-53). Chambering in the dorsal side of the valve is insignificant but is present in the mid-portion on the ventral side (Figs 49, 51). The girdle is composed of one wide, open band with no structure, and a second small segment (Fig. 52). A third girdle element was not 
confidently detected in this case. The two plastids present the typical morphology for the genus (Fig. 39).

This form has been reported commonly during the last 140 years as $A$. ventricosa or $A$. angusta var. ventricosa. It has also been confused with $A$. cymbelloides (Grunow in Schmidt, 1875, pl. 25, figs 10,14 ?) but, as noted already by Cleve (1895), Grunow's species is more delicate. In the original description of $A$. cymbelloides (Grunow, 1867, p. 24), it is stated clearly that the stria density is $>80$ in $0.001^{\prime \prime}($ c. $31.5 \mathrm{in} 10 \mu \mathrm{m})$. As is obvious from our typification of $A$. ventricosa and the decisive differences from $A$. cymbelloides, the full identity of which will be discussed in a subsequent paper, this species is in need of a new name. The material presented here comes from the Messolonghi lagoon complex, western Greece $\left(21^{\circ} 04^{\prime}-21^{\circ} 34^{\prime} \mathrm{E}, 38^{\circ}\right.$ $\left.15^{\prime}-38^{\circ} 36^{\prime} \mathrm{N}\right)$. Additionally, slide 147 of the Cleve \& Möller exsiccata set (BM, Adams collection), which comes from Java, like the specimen figured in A. Schmidt (1875) as A. cymbelloides, was examined and contains specimens referable to $S$. robusta.

There are many reports of species resembling S. robusta (as A. angusta var. ventricosa or A. ventricosa), e.g. by Foged (1984, 1986, 1987), Hendey (1951, 1964), John $(1983,1990)$ and Navarro $(1982 a, b)$. Some of them probably do represent $S$. robusta, although it is difficult to be sure without examining specimens. However, many reports probably refer to other species, with wider valves and fewer striae on both the ventral and dorsal sides (some of these species will be discussed in a subsequent paper).

Seminavis macilenta (Gregory) Danielidis \& D. G. Mann, comb. nov.

Figs 54-68

Amphora macilenta Gregory 1857 (p. 510, fig. 65)

LeCtotype (designated here): BM 3291 England Finder Reference M45/2 (near the 2-4 boundary) (Fig. 55)

IsotyPe: BM 3291 England Finder Reference G33/3 (Fig. 54)

The frustules are lanceolate, $7 \cdot 9-11 \mu \mathrm{m}$ wide in girdle view, with obtusely rounded apices. The valves are semi-lanceolate, $22 \cdot 5-42 \mu \mathrm{m}$ long and $3 \cdot 8-5 \cdot 2 \mu \mathrm{m}$ wide, with a convex dorsal margin and a straight ventral margin (Figs 54-56, 58). The dorsal side of the axial area is typically wide but the ventral side is extremely narrow. The raphe sternum is strongly silicified and separated by a groove from the weakly gibbous dorsal side (Fig. 63). The dorsal mantle is typically deep, with no boundary between it and the valve face (Figs 62, 63, 67).
The raphe is parallel and close to the ventral margin (Figs 54, 56, 58, 62), with almost straight branches that are deflected ventrally at the centre (Figs 56, 63). The apical raphe endings are hooked to the dorsal side (Figs 64, 65). Internally, the raphe runs on a rib that bends towards the dorsal side and twists into a vertical position only at the centre and poles. The central internal raphe endings open onto a small, elongate nodule (Figs 66, 67), while apically the raphe ends in small, ventrally bent helictoglossa (Fig. 66).

The dorsal striae are $11.8-14.2$ in $10 \mu \mathrm{m}$, weakly radiate at the middle and more or less parallel to a little divergent at the apices. The middle stria is usually shorter than the others. The ventral striae are $11 \cdot 8-14.8$ in $10 \mu \mathrm{m}$ and composed of a single areola along the whole length of the valve. The areolae of the dorsal striae are apically elongate and densely arranged, but commonly lose their orientation - as in other species of this genus - turning transapically or at an angle to the apical axis (Figs 62, 65-67); the areola closest to the axial area is occasionally double and stria discontinuities are frequent. The internal areola openings are also slit-like and preserve the external orientation (Figs 66, 67).

The central nodule is thickened and a little expanded dorsally (Figs 56, 63). Internally, the dorsal side of the axial area is wider but no chambering is evident (Fig. 67). A single row of simple pores is present at both valve apices (Figs 64-66). The girdle is composed of unornamented open bands. The first band is wide, with the space between its ends closed by the segmental second band (Fig. 64). The presence of a third element could not be confirmed. The plastid morphology and arrangement are typical of this genus, though simpler than in S. ventricosa (Figs 59-61).

In rough cultures of sublittoral material from Loch Goil, we observed a few auxospores of A. macilenta in May 1989. Auxosporulation was allogamous. The gametangia were fairly loosely associated with each other in pairs, within a diffuse mucilage envelope (Fig. 68a). The gametangial thecae dehisced fully, so that they lay separate after plasmogamy. Two auxospores were produced by each pair of cells. The auxospores were produced between the gametangia and expansion was approximately parallel to the long axes of the gametangia. These characteristics suggest that the auxosporulation of $S$. macilenta can be classified as being of Geitler's (1973) type IB2a. The zygote wall persisted as caps over the ends of the expanding auxospores, which produced a silicified transverse perizonium (Fig. 68b,c), as in other pennate diatoms (Mann, 1982; von Stosch, 1982). The initial cells, which contained two plastids, one inherited from each of the fusing gametes, were asymmetrical 


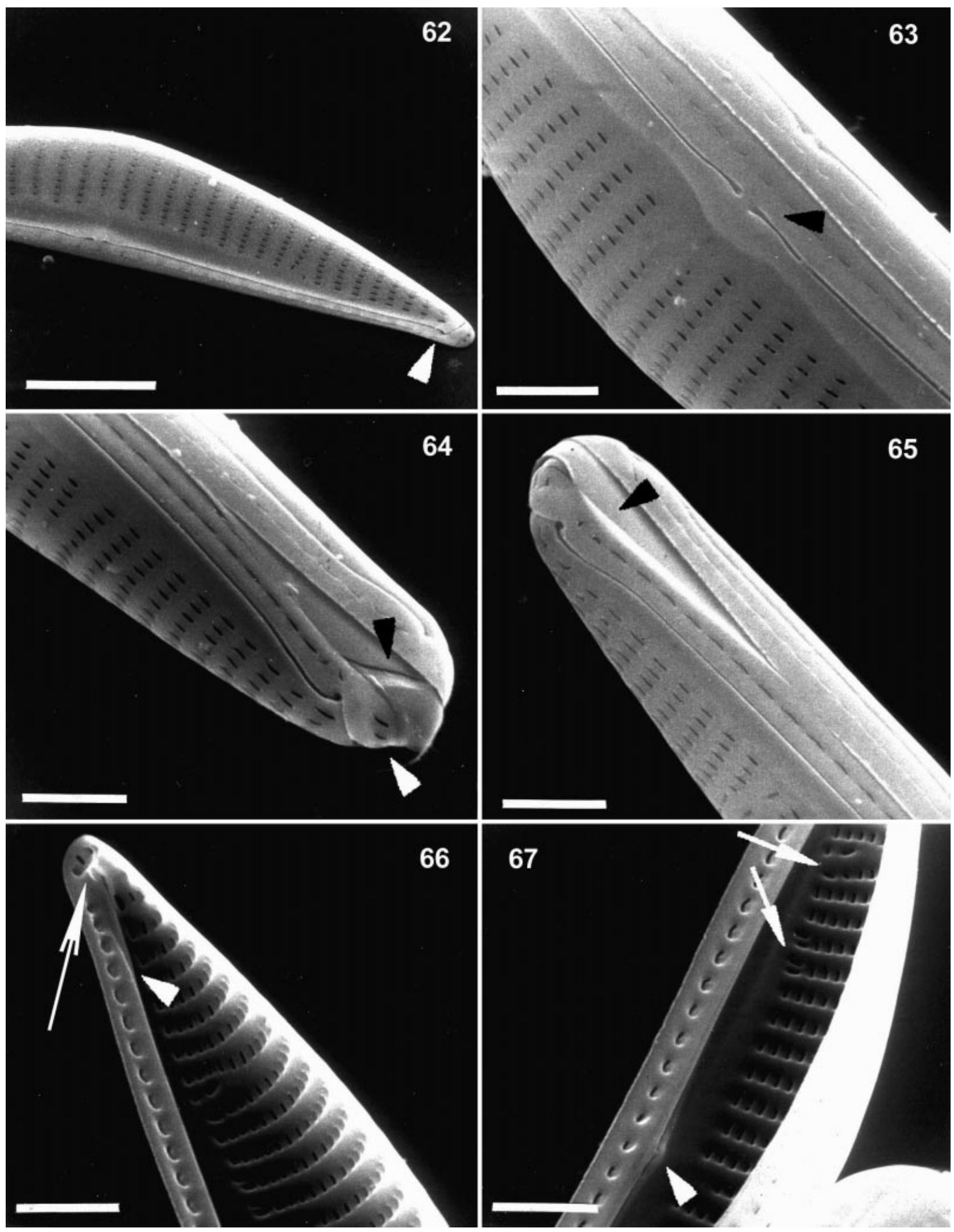

Figs 62-67. Fine structure of Seminavis macilenta. Fig. 62. External view of the valve. Note the position of the raphe and the dorsally hooked apical fissures (arrowhead). Fig. 63. Detail of the mid-valve section, showing the ventral deflections of the central raphe endings (arrowhead) and the slit-like areolae. Fig. 64. Detail of the pole, showing the simple row of apical pores (white arrowhead) and the apical fissures of the raphe. Note the unornamented main girdle band (black arrowhead) and ligula. Fig. 65. Detail of the other pole of the same frustule, showing the closed end of the main girdle band (black arrowhead) and some disoriented areolae. Fig. 66. Internal view of the pole, showing the twisted raphe rib (white arrowhead) and the terminal helictoglossa (white arrow). Note the simple apical pores. Fig. 67. Internal view of the valve, showing the raphe rib and the central nodule (arrowhead). Note the disoriented areolae (arrows). Scale bars represent $2 \mu \mathrm{m}$ (Figs 63-67) or $5 \mu \mathrm{m}$ (Fig. 62). 


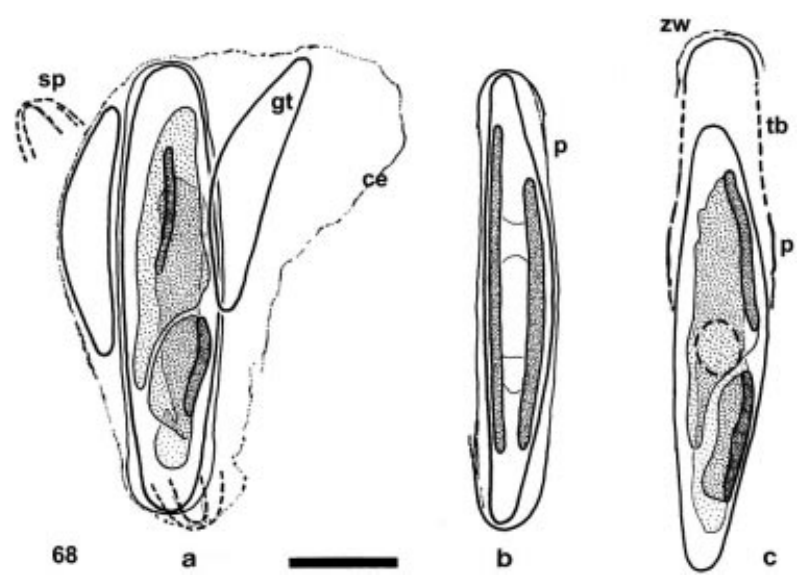

Fig. 68. Camera lucida drawings of Seminavis macilenta auxosporulation. (a) Fully expanded auxospores lying within a wide, irregular and diffuse copulation envelope (ce, margin dotted), still associated with the gametangial thecae (gt). One auxospore (sp) lay out of the plane of focus and this is shown separately in $(b)$; its position is indicated by dashed lines. (b) Initial cell lying in valve view within the perizonium (p) of a fully expanded auxospore. Note that the initial cell is asymmetrical, despite the linear, cylindrical form of the perizonium, as a result of the protoplast contracting away from the perizonium during initial valve formation; it apparently contains two plastids (stippled), lying against the sides of the girdle. (c) Initial cell escaping from the perizonium (p), which can be seen to be transversely banded (tb), with wider bands towards the centre; at the upper pole a cap is visible, representing the remains of the zygote wall (zw). Scale bar represents $20 \mu \mathrm{m}$.

and amphoroid, like the vegetative cells, as a result of a strong contraction of the protoplast away from the perizonium before the formation of the initial epivalve (Fig. 68b, $c$ : compare Fig. 68a). Later, the perizonium became disrupted as the initial cell escaped from it (Fig. 68c).

Amphora macilenta was first described by Gregory (1857, p. 510, Fig. 65) as an 'elliptic form, long and narrow, contracting towards the ends, which are again slightly expanded, and terminate so that it has very short, square, produced ends. Valves very slender, arcuate on dorsal margin, straight on ventral. Middle space narrow, with a strong median line. Length $0.0018^{\prime \prime}[c .46 \mu \mathrm{m}]$ to $0.0022^{\prime \prime}[c .56 \mu \mathrm{m}]$, breadth of entire frustule $0 \cdot 0005^{\prime \prime}$ to $0.0008^{\prime \prime}[c$. $12 \cdot 7-21 \cdot 6 \mu \mathrm{m}]$. Striae parallel, rather coarse, about 30 in $0001^{\prime \prime}$ [c. 11.8 in $10 \mu \mathrm{m}$ ]'. No marked specimen of this taxon could be traced in Greville's collection held at the Natural History Museum, London (BM). Nevertheless, a number of slides exist from the original locality and collection date (e.g. BM 3291). They bear only one diatom that agrees well with Gregory's description, although the specimens have smaller dimensions: the outline of the valves, the stria arrangement and stria density are the same. Gregory noted that the raphe ('median line') is located in the middle of the valve, but this curious statement is probably explained by the inadequate microscope quality and low magnification of that time. What Gregory called a 'strong median line' is probably a dorsal widening of the axial area; the raphe lies so close to the ventral side that it is sometimes difficult to resolve in LM even today. Modern collections of subtidal sediment from Loch Goil (western Scotland) included a taxon identical to A. macilenta as described above and as seen in the slides of the type locality. Our SEM observations are based on this material and show that this species belongs to the genus Seminavis.

Cleve (1895, p. 121) was the first to suggest that A. macilenta and A. ergadensis Gregory (1857) are similar, placing them as varieties under $A$. macilenta. $\mathrm{He}$ expanded the ranges of dimensions for both forms, recognized a 'complex zone' (i.e. a girdle with striation), obscurely punctate striae and declared that the 'median line' (raphe) is close to the ventral side. From the original description and drawings of A. ergadensis, however, it is evident that its girdle should be simple and unornamented (a 'simple' Amphora sensu Gregory 1857) and that the raphe should lie nearer the middle of the valve and have a prominent central nodule. Examination of Greville's slide from Lamlash (the type locality, material collected in 1856) with a ringed individual of A. ergadensis (BM 1362, ring 4: Fig. 57) shows that Gregory's description and figure are accurate. It is evident that Cleve's concept of these species differed from Gregory's original intentions. Amphora ergadensis seems to be a true Amphora species, not a Seminavis, and it is clear that A. macilenta and A. ergadensis are different species.

\section{Discussion}

This paper is the first to deal in detail with the genus Seminavis, which was erected validly but with only a brief description by Round et al. (1990). The artificiality of Amphora, from which Seminavis was split, has been known for over 100 years (Cleve, 1895; Mereschkowsky, 1902-3) but diatomists have procrastinated about revising it (see Mann, 1994). Different groups in Amphora have different valve structure, girdle structure, plastid morphology, and auxosporulation patterns (Round et al., 1990; Mann, 1993, 1994) and are probably related to quite different groups of raphid diatoms. The only thing uniting them is their strong dorsiventrality.

In most cases we do not yet know which other raphid genera the Amphora groups are allied to. For Seminavis it seems indisputable that there is a close relationship to the Naviculaceae sensu Mann (in Round et al., 1990), which includes Navicula Bory, Trachyneis Cleve, Pseudogomphonema Medlin, Rhoikoneis Grunow and possibly Haslea Simonsen and Cymatoneis Cleve. Features in common be- 
tween Seminavis and Navicula include the plastid arrangement and division pattern, pyrenoid morphology, raphe structure, linear areolae and girdle structure (Mann, 1989a, 1996; Mann \& Stickle, 1989; Round et al., 1990; Cox, 1996, 1999).

The single bar-like, non-perforate pyrenoid, with sharp, straight edges and extending along almost the whole length of the chloroplast, is apparently only found in the Naviculaceae sensu Mann, and the transverse division of the plastids and their subsequent diagonal translocation from the valve to the girdle is also characteristic of this group. The raphe structure of Navicula has been well illustrated by Cox (1999) and Round et al. (1990) and exhibits the same basic structure as in Seminavis, with simple, straight internal central raphe endings, hooked external polar raphe endings, and internal raphe fissures that open laterally over most of their length, as the result of an overgrowth of silica from the primary side of the raphe sternum (the ventral side in Seminavis). In addition, Seminavis, like some Navicula species, Pseudogomphonema, Rhoikoneis and Trachyneis, has a small 'chamber' at each pole, beyond the helictoglossa, opening to the exterior by a single line of areolae (compare Figs 17, 38, 53, 66 with illustrations in Round et al., 1990; and see Medlin, 1991). The function of this special group of pores is unknown; only in the attached diatom Pseudogomphonema (Medlin \& Round, 1986) is it likely that the pores are involved in stalk formation. The same trend that is seen in S. ventricosa and $S$. robusta towards internal occlusion of the striae by thin membranes of silica, creating alveoli, occurs also in Pseudogomphonema (P. arcticum (Grunow) Medlin lacks any such overgrowths, whereas P. kamschaticum (Grunow) Medlin has them) and Rhoikoneis (Medlin, 1991). In Navicula too, some species have alveolate striae, e.g. N. walkeri Sovereign (Kociolek et al., 1998), and so it seems likely that either the presence of alveoli, or their absence, or both, show a high degree of homoplasy in the Naviculaceae. Finally, Seminavis, like most Navicula and all known Pseudogomphonema, Rhoikoneis and Trachyneis, has plain girdle bands. Band 1 is almost always much wider than any other band and band 2 is reduced to a small ligulate segment (Medlin, 1985; Medlin \& Round, 1986; Round et al., 1990; Cox, 1999, especially figs 97, 101).

The mode of auxosporulation found in S. macilenta is similar to that found in species of Navicula sensu stricto (for which the published information was summarized by Mann \& Stickle, 1989), although there is variation within the genus with respect to the number of auxospores produced per pair: in some of the $N$. cryptocephala Kützing species complex, only one gamete is produced per gametangium and hence only one zygote per pair (Geitler, 1973). A strong contraction of the auxo- spore protoplast during initial valve formation is seen also in the freshwater species $N$. cryptocephala (Geitler, 1968) and the marine $N$. directa (Wm. Smith) Ralfs in Pritchard (Karsten, 1899). No information is available concerning auxosporulation in Rhoikoneis or Trachyneis; Pseudogomphonema appears to resemble Navicula and Seminavis (D. G. Mann, unpublished observations).

Within the Naviculaceae there are four types of frustule symmetry, namely naviculoid (Navicula, Trachyneis, Haslea and Cymatoneis, although Cymatoneis valves are slightly twisted about the apical axis), achnanthoid (i.e. bent across the median transapical plane, so that the valves are dissimilar: Rhoikoneis), gomphonemoid (Pseudogomphonema) and amphoroid (Seminavis), demonstrating the evolutionary conservatism of valve and raphe structure and plastid ontogeny in this group, relative to frustule symmetry. This is now well documented in pennate diatoms (e.g. Round et al., 1990; Medlin, 1991) but is the reverse of what had been expected, given the traditional reliance on symmetry in diatom classification (cf. Karsten, 1928). The symmetry shift in Seminavis is perhaps the most extreme in the Naviculaceae, since it has involved not only the development of amphoroid shape but also a change in the organization of cell division and valve ontogeny. In Navicula species the nucleus divides alternately on one side of the cell and then on the other, producing a 2:1 ratio of trans to $c$ is frustules (in trans frustules the primary sides of the valves lie on opposite sides of the cell, while in cis frustules they are on the same side: Mann, 1983; Mann \& Stickle, 1988). In Seminavis, however, there is no reorientation of the protoplast and nucleus between cell divisions, so that all frustules can have this cis conformation, with the primary sides of the valves always ventral.

\section{Acknowledgements}

This work would have been impossible to complete without the valuable assistance of Stephen Droop and Frieda Christie. D.G.M. acknowledges with thanks the Royal Society grant that enabled purchase of his photomicroscope. D. B.D. wishes to thank the University of Athens for granting a sabbatical scholarship to work at the Royal Botanic Garden of Edinburgh and especially acknowledges the support of Prof. Athena Economou-Amilli during years of collaboration.

\section{References}

ArChibald, R.E.M. (1983). The diatoms of the Sundays and Great Fish Rivers in the Eastern Cape Province of South Africa. Bibl. Diatomologica, 1: 1-362. 
Brockmann, C. (1950). Die Watt-Diatomeen der schleswigholsteinischen Westküste. Abh. Senckenberg Naturf. Ges., 478: $1-26$.

Cholnoky, B.J. (1960). Beiträge zur Kenntnis der Diatomeenflora von Natal (Südafrika). Nova Hedwigia, 2: 1-128.

Cleve, P.T. (1895). Synopsis of the naviculoid Diatoms. K. Svenska Vetenskaps-Akad. Handl., 26(2): 1-194.

Cleve-Euler, A. (1953). Die Diatomeen von Schweden und Finnland. I-V. K. Svenska VetenskapsAkad. Handl., ser. 4, 4(5): $1-255$.

Coste, M. \& Ricard, M. (1990). Diatomées continentales des îles de Tahiti et de Moorea (Polynésie Française). In Ouvrage dédié à la Mémoire du Prof. H. Germain 1903-1989 (Ricard, M. \& Coste, M., editors), 33-62. Koeltz Scientific Books, Koenigstein.

Cox, E.J. (1996). Determination of Diatoms from Live Material. Chapman \& Hall, London.

Cox, E.J. (1999). Studies on the diatom genus Navicula Bory. VIII. Variation in valve morphology in relation to the generic diagnosis based on Navicula tripunctata (O.F. Müller) Bory. Diatom Res., 14: 207-237.

Droop, S.J.M. (1994). Morphological variation in Diploneis smithii and D. fusca (Bacillariophyceae). Arch. Protistenk., 144: 249-270.

Droop, S.J.M. (1995a). A morphometric and geographical analysis of two races, Diploneis smithii/D. fusca (Bacillariophyceae) in Britain. In Proceedings of the 13th International Diatom Symposium (Marino, D. \& Montresor, M., editors), 347-369. Biopress, Bristol.

Droop, S.J.M. (1995b). Research note: the Universal Striatometer for photographs and other illustrations. Diatom Res., 10: 351356.

Droop, S.J.M. (1996a). The identity of Diploneis splendida (Bacillariophyta) and some related species. Phycologia, 35: 404-420.

Droop, S.J.M. (1996b). Correction: Diploneis splendida is an illegitimate name. Diatom Res., 11 : 381-382.

Droop, S.J.M., Mann. D.G. \& LoKhorst. G.M. (2000). Spatial and temporal stability of demes in Diploneis smithii/D. fusca (Bacillariophyta) supports a narrow species concept. Phycologia, 39: 527-546.

Eaton, J.W. \& Moss, B. (1966). The estimation of numbers and pigment content in epipelic algal populations. Limnol. Oceanogr., 11: 584-595.

EHRENBERG, C.G. (1854-6). Mikrogeologie. Das Erden und felsen schaffende Wirken des unsichtbar kleinen selbststandigen Lebens auf der Erde. Leopold Voss, Leipzig. Texte, 374pp (1854). Atlas, 40 plates (1854). Fortsetzung, 88pp (1856).

EhrenberG, C.G. (1875). Das unsichtbar wirkende Leben der Nordpolarzone am Lande und in den Meerestiefgrunden bei $300 \mathrm{mal}$ verstärkter Sehkraft nach Materialien der Germania erläutert. In Die zweite Deutsche Nordpolarfahrt, Leipzig.

FogED, N. (1975). Some littoral diatoms from the coast of Tanzania. Bibl. Phycologica, 16: 1-25.

Foged, N. (1978). Diatoms in Eastern Australia. Bibl. Phycologica, 41: 1-243.

Foged, N. (1984). Freashwater and littoral diatoms from Cuba. Bibl. Diatomologica, 10: 1-119.

Foged, N. (1986). Diatoms in Gambia. Bibl. Diatomologica, 12: $1-153$.

Foged, N. (1987). Diatoms from Viti Levu, Fiji Islands. Bibl. Diatomologica, 14: 1-128.

Garcia-Baptista, M. (1993). Psammic algae from Praia Azul, Brazil. Bibl. Phycologica, 94: 1-167.

Geitler, L. (1968). Auxosporenbildung bei einigen pennaten Diatomeen und Nitzschia flexoides n. sp. in der Gallerte von Ophrydium versatile. Österr. Bot. Z., 115: 482-490.

GeitLer, L. (1973). Auxosporenbildung und Systematik bei pennaten Diatomeen und die Cytologie von Cocconeis-Sippen. Österr. Bot. Z., 122: 299-321.

Giffen, M.H. (1963). Contributions to the diatom flora of South Africa. I. Diatoms of the estuaries of the Eastern Cape Province. Hydrobiologia, 21 : 201-265.

GifFen, M.H. (1976). A further account of the marine littoral diatoms of the Saldanha Bay Lagoon, Cape Province. Bot. Mar., 19: $379-394$.

GREGORY, W. (1857). On new forms of marine Diatomaceae found in the Firth of Clyde and in Loch Fine. Trans. R. Soc. Edinb., 21: $473-542$.

Greuter, W., McNeill, J., Barrie, F.R., Burdet, H.-M., Demoulin, V., Filgueiras, T.S., Nicolson, D.H., Silva, P.C., Skog, J.E., Trehane, P., Turland, N.T. \& Hawsworth, D.L (2000) International Code of Botanical Nomenclature (St Louis Code). Koeltz Scientific Books, Koenigstein.

Guillard, R.R.L. \& Lorenzen, C.L. (1972). Yellow-green algae with chlorophyllide $c$. J. Phycol., 8: 10-14.

Hendey, N.I. (1951). Littoral diatoms of Chichester Harbour with special reference to fouling. J. R. Microsc. Soc., 71: 1-86.

Hendey, N.I. (1958). Marine diatoms from some West African ports. J. R. Microsc. Soc., 77: 28-85.

Hendey, N.I. (1964). An Introductory Account of the Smaller Algae of British Coastal Waters. Part V: Bacillariophyceae (Diatoms).

Hendey, N.I. (1973). Some benthic diatoms from the coast of Cornwall, in the neighborhood of Porthleven. Nova Hedwigia, Beih., 45: 291-332.

Hustedt, F. (1931-59). Die Kieselalgen Deutschlands, Österreichs und der Schweiz unter Berücksichtigung der übrigen Länder Europas sowie der angrenzenden Meeresgebiete. In Dr. Rabenhorst's Kryptogamen-Flora von Deutschland, Österreich und der Schweiz, vol. 7, part 2. Akademische Verlagsgesellschaft, Leipzig.

Hustedt, F. (1955). Marine littoral diatoms of Beaufort, North Carolina. Bull. Duke Univ. Mar. Station, 6: 1-67.

Jin, D.-X. (Chin, T.G.), Cheng, Z.-D., Lin, J.-M. \& Lin, S.-C. (1985). The Marine Benthic Diatoms in China, vol. 1. China Ocean Press, Beijing \& Springer-Verlag, Berlin.

JoHn, J. (1983). The diatom flora of the Swan River Estuary, Western Australia. Bibl. Phycologica, 64: 1-204.

JoHN, J. (1990). The diatom flora of the microbial communities associated with stromatolites at Shark Bay, Indian Ocean, West Coast of Australia. In Ouvrage dédié à la Mémoire du Prof. H. Germain 1903-1989 (Ricard, M. \& Coste, M., editors), 97-110. Koeltz Scientific Books, Koenigstein.

Karsten, G. (1899). Die Diatomeen der Kieler Bucht. Wiss. Meeresunters., Abt. Kiel, N. F., 4: 17-205.

Karsten, G. (1928). Abteilung Bacillariophyta (Diatomeae). In Die natürlichen Pflanzenfamilien, 2nd edn, vol. 2 (Engler, A., editor), 105-303. W. Engelmann, Leipzig.

Krammer, K. \& Lange-Bertalot, H. (1986-1991). Bacillariophyceae. Parts 1-4. In Süsswasserflora von Mitteleuropa (Ettl, H. et al., editors). G. Fischer, Stuttgart.

Kuylenstierna, M. (1989). Benthic Algal Vegetation in the Älv Estuary (Swedish West Coast). Vol. 1, text 244 pp; Vol. 2, 76 plates. Department of Marine Botany. University of Göteborg, Göteborg, Sweden.

ManN, D.G. (1982). Structure, life history and systematics of Rhoicosphenia (Bacillariophyta). II. Auxospore formation and perizonium structure of Rh. curvata. J. Phycol., 18: 264-274.

MANN, D.G. (1983). Symmetry and cell division in raphid diatoms. Ann. Bot., 52: 573-581.

MANN, D.G. (1984). Observations on copulation in Navicula pupula and Amphora ovalis in relation to the nature of diatom species. Ann. Bot., 54: 429-438.

Mann, D.G. (1989a). The diatom genus Sellaphora: separation from Navicula. Br. Phycol. J., 24: 1-20.

MANN, D.G. (1989b). The species concept in diatoms: evidence for morphologically distinct, sympatric genodemes in four epipelic species. Plant Syst. Evol., 164: 215-237.

ManN, D.G. (1993). Patterns of sexual reproduction in diatoms. Hydrobiologia, 269/270: 11-20.

ManN, D.G. (1994). The systematics of amphoroid diatoms: the life history of Amphora arcus. Nova Hedwigia, 58: 335-352.

ManN, D.G. (1996). Chloroplast morphology, movements and inheritance in diatoms. In Cytology, Genetics and Molecular Biology of Algae (Chaudhary, B.R. \& Agrawal, S.B., editors), 249-274. SPB Academic Publishing, Amsterdam. 
Mann, D.G. (1999). The species concept in diatoms. Phycologia, 38 : 437-495.

ManN, D.G. \& Droop, S.J.M. (1996). Biodiversity, biogeography and conservation of diatoms. Hydrobiologia, 336: 19-32.

Mann, D.G. \& Stickle, A.J. (1988). Nuclear movements and frustule symmetry in raphid pennate diatoms. In Proceedings of the 9th International Diatom Symposium (Round, F.E., editor), 281-289. Koeltz Scientific Books, Koenigstein and Biopress, Bristol.

Mann, D.G. \& STickle, A.J. (1989). Meiosis, nuclear cyclosis, and auxospore formation in Navicula sensu stricto (Bacillariophyta). Br. Phycol. J., 24: 167-181.

Mann, D.G. \& Stickle, A.J. (1991). The genus Craticula. Diatom Res., 6: 79-107.

Meduin, L.K. (1985). A reappraisal of the diatom genus Rhoiconeis and the description of Campylopyxis, gen. nov. Br. Phycol.J., 20: 313-328.

MedLin, L.K. (1991). Evidence for parallel evolution of frustule shape in two lines of pennate diatoms from the periphyton. Diatom Res., 6: 109-124.

Meduin, L.K. \& Round, F.E. (1986). Taxonomic studies of marine gomphonemoid diatoms. Diatom Res., 1: 205-225.

MeresChKowsky, C. (1901). Etudes sur l'endochrome des diatomées. Zap. Imp. Akad. Nauk, ser. 8. 11(6): 1-40.

Mereschkowsky, C. (1902-3)). Les types de l'endochrome chez les diatomées. Bot. Zap., 21 : 107-193.

Metzeltin, D. \& Witkowski, A. (1996). Diatomeen der BärenInsel. Süsswasser-und marine Arten. Iconographia Diatomologica, 4: 1-232.

Mills, F.W. (1933-5). An Index to the Genera and Species of the Diatomaceae and their Synonyms 1816-1932. Wheldon \& Wesley, London.

MONTGOMERy, R.T. (1978). Environmental and ecological Studies of the Diatom Communities Associated with the Coral Reefs of the Florida Keys, vol. II. PhD thesis. Florida State University, Florida.

NAVARro, J.N. (1982a). Marine diatoms associated with mangrove prop roots in the Indian River, Florida, U.S.A. Bibl. Phycologica, 61: $1-65$.

Navarro, J.N. (1982b). A survey of the marine diatoms of Puerto Rico. V. Suborder Raphidineae: Families Achnanthaceae and Naviculaceae (excluding Navicula and Mastogloia). Bot. Mar., 25: 321-338.

Pankow, H. (1990). Ostsee-Algenflora. Gustav Fischer, Jena.

PARK, R.A. (1992). The Ecology of Epipelic Diatoms in Loch Goil. $\mathrm{PhD}$ Thesis, University of Edinburgh.

Peragallo, H. \& Peragallo, M. (1897-1908). Diatomées marines de France et des districts maritimes voisins. Grez-sur-Loing.

Proshrina-Lavrenko, A.I. (1963). Diatomovye vodorosli bentosa Chernogo morya. Izdatel'stvo Akademii Nauk SSSR, Moscow.
RicARD, M. (1977). Les peuplements de diatomées des lagons de l'Archipel de la Société (Polynésie Française). Floristique, écologie, structure des peuplements et contribution à la production primaire. Rev. Algol., 12: 143-336.

Ricard, M. (1987). Atlas du Phytoplancton Marin. Vol. II: Diatomophycées. Editions du Centre National de la Recherche Scientifique, Paris.

Round, F.E., Crawford, R.M., \& Mann, D.G. (1990). The Diatoms: Biology \& Morphology of the Genera. Cambridge University Press, Cambridge.

Schmidt, A. (1874). Die in den Grundproben der Nordssefahrt vom 21. Juli bis 9. September 1872 enthaltenen Diatomaceen. Erste Folge. Jahresbericht der Commission zur wissenschaftlichen Untersuchung der Deutschen Meere in Kiel, 2: 83-95. Wiegande, Hempel \& Parey, Berlin.

Schmidt, A. (1874-1959). Atlas der Diatomaceenkunde. Reisland, Leipzig.

SimONSEN, R. (1962). Untersuchungen zur Systematik und Ökologie der Bodendiatomeen der westlichen Ostsee. Int. Rev. Ges. Hydrobiol., Syst. Beih., 1: 1-144.

Simonsen, R. (1974). The diatom plankton of the Indian Ocean Expedition of R/V Meteor. Meteor Forschungsergebnisse, Reihe $D, 19: 1-66$.

Skvortzow, B.W. (1927). Diatoms from Tientsin, North China. J. Bot., 102-109.

Skvortzow, B.W. (1932a). Marine diatoms from the Kanazawa Oyster experimental station of Japan. Philipp. J. Sci., 47: 119-127.

Skvortzow, B.W. (1932b). Marine littoral diatoms from environs of Vladivostok. Philipp. J. Sci., 47: 129-150.

Skvortzow, B.W. (1932c). Marine diatoms from Formosa Strait. Philipp. J. Sci., 47: 151-161.

Skvortzow, B.W. $(1932 d)$. Diatoms from the bottom of the sea of Japan. Philipp. J. Sci., 47: 265-280.

Stosch, H.A. von. (1982). On auxospore envelopes in diatoms. Bacillaria, 5: 127-156.

Sullivan, M.J. (1990). A light and scanning electron microscope study of the marine epiphytic diatom Amphora obtusiuscula Grunow. In Ouvrage dédié à la Mémoire du Prof. H. Germain 1903-1989 (Ricard, M. \& Coste, M., editors), 251-258. Koeltz Scientific Books, Koenigstein.

Van Heurck, H. (1896). A Treatise on the Diatomaceae. Translated by Wynne E. Baxter. Wesley, London.

Van Landingham, S.L. (1967). Catalogue of the Fossil and Recent Genera and Species of Diatoms and their Synonyms. Part I. Acanthoceras through Bacillaria. J. Cramer, Lehre.

Witkowski, A. (1994). Recent and fossil diatom flora of the Gulf of Gdansk, Southern Baltic Sea. Origin, composition and changes of diatom assemblages during the Holocene. Bibl. Diatomologica, 28: $1-313$. 